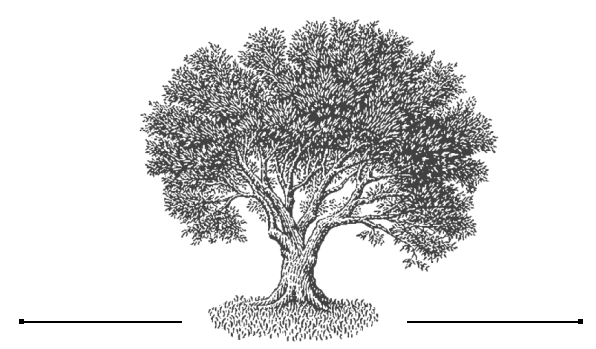

\section{Псалтирь на}

церковнославянском,

греческом и

Польском языках из

библиотеки

Симона Азарьина

\section{Елена Александровна Целунова}

Институт отельного бизнеса

Прага, Чехия

\section{The Book of Psalms in the Church Slavonic, Greek, and Polish Languages from Simon Azarjin's Library}

\author{
Jelena A. Celunova \\ Institute of Hospitality Management \\ Prague, Czech Republic
}

\title{
Резюме
}

Статья посвящена исследованию рукописной Псалтири первой половины XVII века из книжной коллекции Симона Азарьина. Псалтирь написана интерлинеарно на трех языках: церковнославянском, греческом и польском. Наличие польского текста в православной псалтири делает этот памятник уникальным. Целью исследования является выяснение того, кем и с какой целью эта Псалтирь была создана. Отсутствие предисловия и каких-дибо указаний об авторе, времени и месте создания перевода заставдяет обратиться к косвенным данным, а именно - к текстологическому исследованию и к анадизу церковнославянского и подьского языков рукописи. Текстодогическое исследование церковнославянского текста Псалтири выявидо его соответствие дониконовским текстам, а анадиз польского текста позволяет утверждать, что автор пользовался католической Библией Деополиты 1561 года, подвергая ее сильной редакции - как текстологической, так и языковой. Анализ внесенных в польский текст и язык изменений позволяет предположить, что автором рукописи мог быть выходец из Западной Руси, при этом сам текст был скорее всего создан в Троице-Сергиевом монастыре. 
Стремление приспособить польский текст к церковнославянскому свидетельствует о том, что треязычная псалтирь могла быть создана для жителей бывших территорий Ведикого княжества Аитовского, конвертирующихся из католицизма или из унии в православие. Подьский текст в этом случае был нужен именно для того, чтобы будущий православный верующий понимал церковнославянский язык богослужения.

Ключевые слова

псалтирь, перевод, церковнославянский язык, польский язык, интерлинеарный текст, Троице-Сергиев монастырь, Симон Азарьин

\section{Abstract}

This article is devoted to research on the Book of Psalms manuscript written in the first half of the 17th century from Simon Azarjin's book collection. The Book of Psalms is written inter-linearly in three languages: Church Slavonic, Greek, and Polish. The availability of the text in Polish in the Orthodox psalms makes this memorable text unique. The research concentrates on the clarification of the aim that led to the creation of the Book of Psalms. The lack of a preface or any other evidence of its author, time, or place of its translation forces us to turn to indirect facts, namely, to research of the textological character and to an analysis of Church Slavonic and Polish texts. Textological research of the Church Slavonic edition of the Book of Psalms reveals its similarity with preNikonian texts and the analyses of the text in Polish allows us to affirm that the author had used the Catholic Leopolita's Bible in 1561, exposed it to a profound edition-both textological as well as linguistic. The analysis of the inserted changes into the text in Polish and the alternated language itself enables us to assume that the author of the manuscript might have been a native from West Russia, while the text itself had probably been created in the Trinity Monastery of St. Sergius. The efforts aimed at adaptation of the Polish text into the text in Church Slavonic prove that the tri-lingual Book of Psalms might have been created for the inhabitants of the previous territories of Great Principality of Lithuania who converted from the Catholic Church or from the Greek Catholic into the Orthodox Church. The text in Polish had thus been needed especially for those believers practicing the Orthodox religion in order to understand the Church Slavonic language of worship.

Keywords

Book of Psalms, translation, Church Slavonic language, Polish language, interlinear text, Trinity Monastery of St. Sergius, Simon Azarjin

Предметом настоящего исследования является малоизвестная в научном сообществе рукопись из библиотеки Симона Азарьина, хранящаяся в рукописном собрании Российской государственной библиотеки и доступная в электронной фотокопии на сайте Троице-Сергиевой лавры [ПсСA]. В описи эта книга озаглавлена как “Псалтирь на славяно-греческом и польском языках”, но, поскольку титульного листа у рукописи 
нет, ее исконное название неизвестно. Эта рукописная книга представляет собой Псалтирь, написанную интерлинеарно на трех языках: сначала идет строка с текстом на церковнославянском (далее - цсл.) языке, под ней тот же текст на греческом языке, а под ним на польском. Греческий и польский тексты являются подстрочным переводом цсл. текста Псалтири. В данной структуре можно найти отступления, о которых будет сказано ниже. Рукопись была коротко описана наместником Троице-Сергиевой лавры архимандритом ЛЕонидом (КАВЕлиным) [1883:7-8].

Размер рукописи в лист, текст написан на 239 листах, в начале и в конце находятся пустые листы (восемь в начале и пять в конце). Первоначальная нумерация листов не сохранилась, настоящая полистовая карандашная нумерация относится к более позднему времени и принадлежит, скорее всего, архимандриту Леониду (Кавелину), просматривавшему рукопись и делавшему в ней отметки карандашом.

Рукопись написана на бумаге иностранного производства. На филигранях изображен “рог изобилия” в гербовом щите, под которым написаны литеры MIENVFRIN1. Датировка рукописи по водяным знакам 1642-1647 гг. [ДиАновА, КостюхинА 1980: 134, № 1147].

Книга написана чернилами, при этом цсл. текст написан полууставом XVII века, греческий текст - курсивом, а польский текст - польской разновидностью готического шрифта. Цсл. текст рукописи написан более темными чернилами, что визуально его выделяет. Начальные буквы цсл. текста псалмов отсутствуют - вероятно, предполагалось дописать их чернилами или киноварью другого цвета. Книга переплетена, сохранились две застежки. На первом пустом листе находится запись, сделанная чернилами скорописью XVIII века: “Псалтырь на славенскомъ греческомъ и польскомъ языкахъ” и несколько владельческих номеров. Владельческие номера были поставлены в Троице-Сергиевой Лавре и соответствуют номеру этой рукописной книги по проводившимся в лавре описям ${ }^{2}$.

По нижнему полю рукописи (далее - ПсСA), начиная с первого листа, через лист написана вкладная запись следующего содержания:

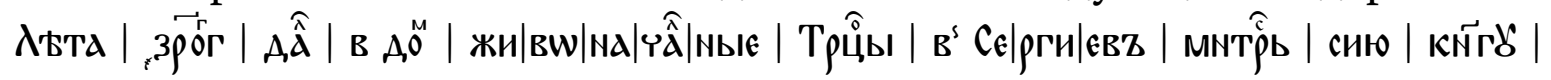

1 Выражаю глубокую благодарность Т. М. Мосоловой и О. Стариковой за помощь в определении филиграней рукописи.

2 Следует отметить, что в самом раннем после поступления книги в ТроицеСергиеву лавру монастырском учете, сделанном в 60-е годы XVII в., в перечне вкладных книг, оставленных Симоном Азарьиным, рукопись озаглавлена как "Книга на трех языках, в десть, письменая" и фигурирует под номером 1 ( $\vec{a})$

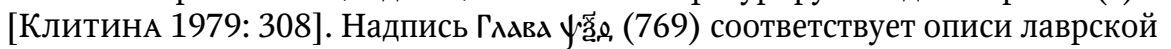
библиотеки 1723 года, номера ГАдва рӓг (143), 3037, зачеркнутые номера № 142 и № 24 также, вероятно, являются номерами монастырского учета второй половины XVIII и XIX веков. 


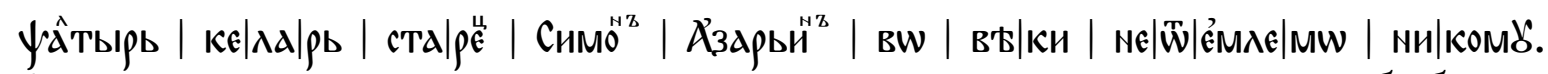
Аналогичная вкладная запись присутствует на всех книгах из библиотеки Симона Азарьина, и одно время исследователи предполагали, что сделана она рукой самого Симона Азарьина [Клитина 1979: 304]. Однако сравнение этой записи с автографами Симона Азарьина опровергает это мнение [Клосс 1998: 228], и сейчас исследователи считают, что вкладные записи были сделаны его личным писцом [ОПАрина 1998: 197]. Из этой вкладной записи следует, что Псалтирь поступила в Троице-Сергиеву Лавру в 1665 (7173) году в составе библиотеки Симона Азарьина - выдающегося писателя XVII века, автора “Жития преподобного Сергия”, казначея и келаря Троице-Сергиева монастыря. Симон Азарьин был известным собирателем книг и оставил после своей смерти (предположительно в 1665 году) значительную по тому времени библиотеку (около 100 книг), в которой можно найти рукописные и печатные книги разного содержания. Рукопись, таким образом, могла быть написана не позже 1665 года.

Следует отметить несколько характерных текстологических особенностей рукописи ПсСА. Псалмы в ней не делятся на стихи, а идут сплошным текстом. При этом визуально трудно определить, где заканчивается один псалом и начинается другой, поскольку каждый лист целиком занят текстом на трех языках, а на полях находятся вставки пропущенного текста и отдельных слов (возможно, что для визуального отделения псалмов предполагалось использовать чернила другого цвета, но этот замысел не был приведен в исполнение). Как уже отмечалось, рукопись написана на трех языках, и под каждой строкой, написанной на цсл. языке, следует ее перевод сначала на греческий, а потом на польский язык. Хотя цсл. текст написан полууставом без разбивки на слова, создатель рукописи явно старался там, где это возможно, приводить греческие и польские слова строго под их цсл. оригиналом, делая даже те же переносы слов. Однако, начиная со второго псалма, мы находим перед каждым псалмом краткое изложение содержания этого псалма (без разбивки на стихи), но только на польском языке. Известно, что такого рода комментарии к псалмам (так называемые аргументы) были характерны для польских текстов Псалтири, но в православной церкви были не приняты, в силу чего они отсутствуют в цсл. и греческой Псалтири ${ }^{3}$.

3 Исключением является рукописная Псалтирь на “простом” языке Аврамия Фирсова, созданная в Москве в 1683 году, в которой перед каждым псалмом написаны аргументы (но только в рукописях, восходящих к более раннему варианту перевода). Все они переведены из польской Брестской библии [ЦЕлуновА 2006]. Из печатных изданий Псалтири аргументы к псалмам можно впервые найти в Псалтири, изданной в Киеве в 1715 году [Пс1715]. Е. Ф. Карскому были известны две западнорусские рукописные славянские Псалтири XVII в. с аргументами [КАРский 1896: 89-90; IDEM1908: 72]. Следует 
На л. 3об. после окончания 3-го псалма в польском тексте читаем: "Chwała oycu y synowi y Duchowi .ŝ. Ninie y zawj̇ dy y na wieki wiekow. Amen. Alleluia Alleluia ${ }^{4}$ Chwała tobie Boje. 3 kroć. Panie zmiluysie, 3 kroć. chwała оусu y Ninie: \&c. tak maß mowic za każdu słwu [u исправлено на $a .-E$. Ц.]. y kaphisma”. Это замечание присутствует только в польском тексте ${ }^{5}$ и соответствует Уставу чтения Псалтири на православном богослужении, в котором говорится, что на Славах следует произносить: “Слава Отцу и Сыну и Святому Духу, и ныне и присно и во веки веков. Аминь. Аллилуия, аллилуия. Слава Тебе, Боже (трижды). Господи, помилуй (трижды). Слава Отцу и Сыну и Святому Духу, и ныне и присно и во веки веков. Аминь”. В цсл. и греческом текстах это замечание отсутствует. Аналогичные указания встретились в польском тексте ПсСА еще несколько раз: на л. 6об. в конце 7-го псалма написано "Alleluia 3 kroć”; на лл. 42об., 49, 53, 59об., 106об., 175 в конце псалмов 36, 39, 42, 45, 73, 108 написано "Chwała”; на лл. 18, 960б., 171 в конце 17, 69, 106 псалма "Chwała оуси”; на л. 20об. после 20 псалма "Chwała оусu у synu”; на лл. 88об., 92, 163об., 181, 200об. после псалмов 66, 67, 104, 114, 123 Chwała oусu у sy: y Duchowi. s..”.

118-й псалом, составляющий 17-ю кафизму, разделен в соответствии с православной традицией на три части (“Славы”), озаглавленные как

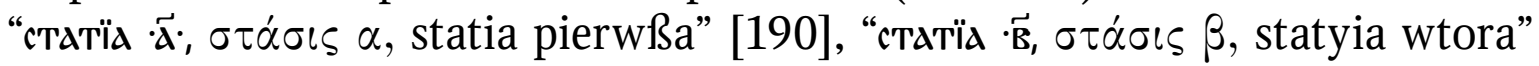

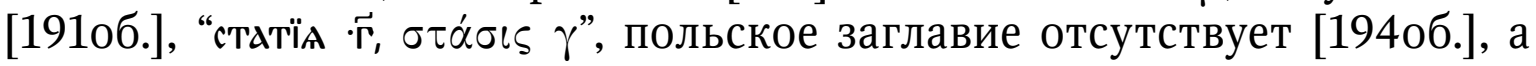
также в соответствии с еврейской традицией делится на части, каждая из которых озаглавлена буквой еврейского алфавита. Однако в тексте находим только 18 буквенных обозначений вместо 22 (Gimel, Daleth, He, Wau, Zain, Heth, Teth, Lame[d], Mem, Nun, Samech, Ain, Phe, Sadic, Koph, Resz, Schin, Thau), остальные писец забыл написать или же они были срезаны при переплете книги.

отметить наличие аргументов в другом библейском тексте - в двух греческоцерковнославянских рукописях Нового Завета, созданных в последней трети XVII в. справщиками Московского Печатного двора в процессе работы над новым переводом Библии. Источником аргументов является польский Новый Завет Якуба Вуйка 1593 г., а также еще какой-то, пока не установленный, новозаветный текст [ПЕНтКОВСКАЯ 2016Б: 194].

4 Так называемое "сугубое” повторение слова аллилуйя характерно для богослужебных текстов, написанных до реформ патриарха Никона. "Сугубая" аллилуйя свидетельствует о написании рукописи в дониконовскую эпоху.

5 Польская формулировка молитвы ninie y závżdy y na wieki wiekow. amen встречается и в других памятниках письменности, напр., в произведениях Петра Скарги [SłP XVI 18: 399] или в изданной в Кракове в 1532 г. Псалтири, где эта молитва является восьмым стихом первого псалма, а потом повторяется (часто в сокращенном виде) после окончания некоторых других псалмов: “Chwała oycu i sinu y duchu swietemu. iako była na początku y ninie y záwżdy y na wieki wiekom. Amen” [P1532 1: 8]. 
Еще одной текстологической особенностью ПсСА является то, что она содержит 151-й псалом. Этот псалом [ПсСА, л. 223] и следующие за ним избранные песни [ПсСА, л. 223об.-237об.] подстрочно переведены только на греческий язык, но при этом под греческим текстом оставлены пропуски, позволяющие предполагать, что и их тоже собирались перевести на польский язык. На л. 238-238об. находится Песнь Пресвятой Богородице "Величит душа моя господа" на четырех языках: цсл., греческом, латинском и польском. После ее окончания на л. 238об.239об. Песнь Захарии - опять только по-церковнославянски и по-гречески. Рукопись заканчивается кратким текстом на греческом языке.

Рукопись ПсСА представляет интерес прежде всего тем, что в ней наряду с цсл. и греческим текстом Псалтири находится польский текст. Если славяно-греческие интерлинеарные тексты Псалтири в рукописных собраниях XVII века хотя и редко, но встречаются ${ }^{6}$, то наличие польского текста делает эту рукопись уникальной. B XVII веке в Московской Руси был заметен интерес к переводу текстов священного писания с польского на цсл. язык. Так, известно, что польская Библия Якуба Вуйка 1599 года стала источником для перевода на цсл. язык книги Иова, выполненного монахом Чудова монастыря Моисеем в 1671 году [ИСАЧЕНКО 2002; ПЕНТКОВСКАЯ 2016А], к ПольсКИм текстам - прежде всего к библии Вуйка - обращались во второй половине XVII века справщики Московского Печатного двора при переводе на цсл. язык Нового Завета [ПентковскАя 2016Б], а московский книжник Аврамий Фирсов при переводе Псалтири на “простои обыклои словенскои” язык обращался сразу к трем польским текстам Псалтири - из Библии Вуйка 1599 г., из Брестской Библии 1563 г. и из Гданьской Библии 1632 г. [ЦЕлуновA 2006]. Тем не менее, случаев перевода текста Священного писания с цсл. на польский язык в Московской Руси того времени не известно 7 .

В связи с этим возникает вопрос, является ли польский текст ПсСА переводом с цсл. или же был целиком позаимствован из какой-то польской Псалтири. Наличие в польском тексте ПсСА аргументов к псалмам

6 Две интерлинеарные славяно-греческие рукописные Псалтири находятся в собрании Московской духовной академии [Пс8; Пс9], причем первая из них также принадлежала Симону Азарьину. Обе рукописи были созданы в ТроицеСергиевом монастыре в первой трети XVII века в связи с работой по сохранению наследия Максима Грека, которая велась под руководством архимандрита Дионисия Зобниновского [ВеРнЕР 2017: 41], и обнаруживают определенное текстологическое и языковое сходство. Сближает их также то, что в обеих рукописях греческий текст написан кириллическими буквами.

7 В то же время такого рода переводы в это время встречаются в Юго-Западной Руси. Например, в 1638 г. в Евье была издана переведенная с цсл. языка на польский Псалтирь, в которой начальные стихи каждого псалма написаны на цсл. языке [Сопиков 1813: 280, № 1737; Ундольский 1871: 57, № 461; КнигА БЕЛОРУССИи 1986: 107, № 129]. 
заставляет искать польский источник прежде всего среди тех библейских текстов, которые содержат аргументы. Таких библий несколько: это уже упоминавшиеся католическая Библия Якуба Вуйка 1599 г. [В99], протестантская Брестская Библия 1563 г. [B63] и Библия Шимона Будного 1572 г. [B72], а также Псалтирь Врубеля 1528 г. [PV], Псалтирь Миколая Рея 1548 г. [PR] и Библия Леополиты 1561 г. [BL]. Текстологическое сравнение всех перечисленных польских источников с аргументами к псалмам польского текста ПсСА позволяет однозначно утверждать, что польским источником рукописи является католическая Библия Леополиты 1561 г. $^{8}$

Приведем несколько примеров перевода аргументов в Таблище 19:

\section{Таблицза 1}

\begin{tabular}{|l|l|l|}
\hline № пс. & \multicolumn{1}{|c|}{ ПсСА } & \multicolumn{1}{|c|}{ Библия Леополиты } \\
\hline 7 & $\begin{array}{l}\text { Ten psalm iest o newim (исправлено: } \\
\text { nn)ośći pána jezusa, y o iego w niebo } \\
\text { wstupieniu, ktory spiewał p. Dáwid: a } \\
\text { sa słowá chuzy syna iemini [5]. }\end{array}$ & $\begin{array}{l}\text { Ten Psalm iest o niewinności Páná Jezu- } \\
\text { sá y o iego w Niebo wstąpieniu, ktory } \\
\text { spiewał Pánu Dawid a sa słowá Chuzy } \\
\text { syna Jemini [528]. }\end{array}$ \\
\hline 53 & $\begin{array}{l}\text { Ucży Prorok cżłowieká sprawedli- } \\
\text { wego, aby w preciwienstwach umiał } \\
\text { chwálic Bogá [71oб.]. }\end{array}$ & $\begin{array}{l}\text { Ucży Prorok ç̇łowieka sprawiedliwego / } \\
\text { aby w przeciiwnościach umiał chwálic } \\
\text { Bogá [548]. }\end{array}$ \\
\hline 129 & $\begin{array}{l}\text { Modlitwa osobliwa káiacego sie á poku- } \\
\text { tuiacego ç̇łowieká, ktory prosi áby go } \\
\text { pán wolnym od grzechow ucżynił [203]. }\end{array}$ & $\begin{array}{l}\text { Modlitwá osobliwa káiącego sie á poku- } \\
\text { tuiącego ç̇łowieká / ktory prośi áby go } \\
\text { Pan wolnym od grzechow uç̇ynił [582]. }\end{array}$ \\
\hline
\end{tabular}

Дальнейший текстологический анализ подтвердил, что автор ПсСА обращался к тексту Псалтири из Библии Леополиты, постоянно сверяя его с цсл. текстом и оставляя без изменения только те фрагменты, которые т е к с т у а л н о совпадали с цсл. Псалтирью, и изменяя порядок слов, отдельные слова и фразы, а также опуская некоторые фрагменты в тех случаях, когда этого требовал текст цсл. Псалтири. Такой творческий

8 Библия Леополиты (далее $-B L$ ) является первой полной католической Библией на польском языке. Первое издание вышло в Кракове в 1561 г., в 1575 г. вышло второе издание, а в 1577 г. - третье. В 1579 г. отдельно была переиздана Псалтирь. “Леополита" - имя редактора Библии Яна Леополиты, профессора Краковской академии, знавшего латинский, греческий и древнееврейский языки. Редактируя перевод Библии, он пользовался не только Вульгатой, но также греческим текстом и чешской Библией 1549 г. [FRICK 1989: 51-66; PIETKIEWICZ 2002: 215-230]. Это пока единственный известный нам случай, когда Библия Леополиты была использована русскими книжниками для перевода.

9 Здесь и далее при передаче старых текстов мы старались придерживаться орфографии оригиналов, иногда ее немного упрощая и сохраняя при этом все надстрочные знаки, кроме знаков ударения и придыхания. В скобках указывается лист рукописи ПсСА или страница из Библии Леополиты. 
подход к исходному польскому тексту из Библии Леополиты позволяет считать, что перед нами перевод цсл. текста Псалтири на польский язык, явившийся результатом редакции исходного текста из Библии Леополиты. Для иллюстрации приведем в Таблице 2 текст 10-го псалма из ПсСА (приводится только цсл. и польский тексты, греческий текст не является предметом настоящего исследования) и из Библии Леополиты ${ }^{10}$.

\section{Таблица 2}

[9об.-10] (1) В конецZ. Ү

(1) Psalm Dawidow 10.

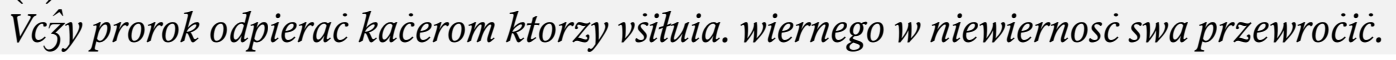

(1) Psalm Dawidow 10.

Vczy Prorok odpierac் kaċerzom / kthorzy vṡiłuią. wiernego w niewierno $\ddot{s}$ swą przewrocicic.

(1) [N]а Га оупова

(2) W pane duffanie mam iakoẑ wy mowiciie dußy moiey / przeñes sie na gory iako wrobl,

(2) W Panie swym duffanie mam: iakoż wy mowicie dussy moiey /przenieś sie na gorę iako wrobl.

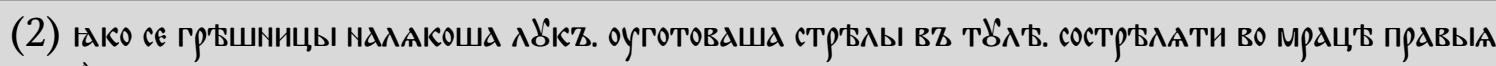
с.рцемz.

(3) boc oto grzeßnicy wyciagnuti tuk / nagotowali strzaty swe w saydak / aby postrzelali $z$ cienia / tych ktorzy su vprzeymego serca.

(3) Boć oto grzessnicy wyciągnęli łuk: nagotowali wssystkie strzały w tule swoim / aby postrzelili serca prawych z cienia.

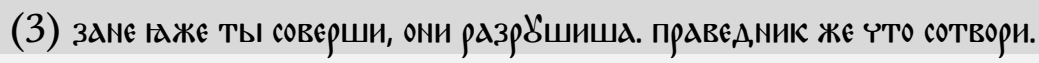

(4) abowem cos ty byt sprawit. oni skaẑili / sprawiedliwy co ucẑynit:

(4) abowem cos thy był sprawił. oni skażili: a sprawiedliwy cżłowiek co ucẑynił:

(4) Г̆ испЫтАєТ' сйЫ чЙчєкїА.

(5) pan w Cerkwie Swietey swoiey / pan w niebiesiech stolica ie ocẑy iego na vbogiego patrza /, powiek iego pytaia synow ludzkich.

(5) Pan w kö̈ciele święthym swoim: Pan w niebiesiech stolica iego. Ocży iego zawżdy na vbogiego patrzą: powieki ocżu iego pytaią synow ludzkich.

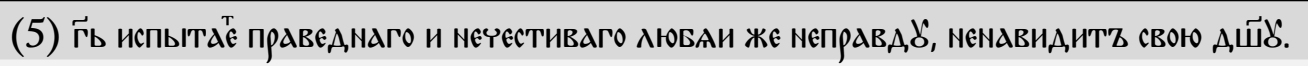

(6) pan pyta prawe y nieprawego / ale kto sie kocha we złosci / nienawidżi swoiey duße.

(6) Pan pyta prawego y nieprawego: ale ten kthory sie we złoscii kocha: nienawidzi dusse swoiey.

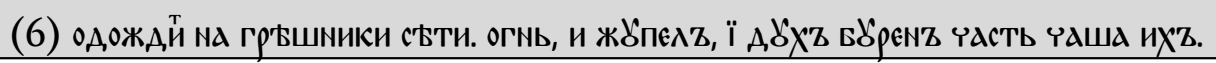

10 Тексты даны в следующей последовательности: цсл. текст ПсСА (с нумерацией стихов согласно Септуагинте), затем выделенный курсивом польский текст из ПсСА, а под ним текст из Библии Леополиты (нумерация стихов польской Библии следует Вульгате). В первых двух строках дается текст аргументов, поэтому цсл. текст отсутствует. 


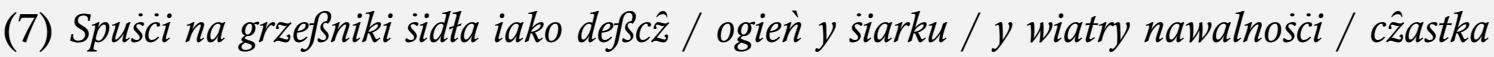
kielicha ich.

(7) Spuści na grzeßniki sidła iako desscż / ogieň y siarkę / y wiatry nawalnoṡci (a tho będzie) cżąstka kielicha a trapienia ich.

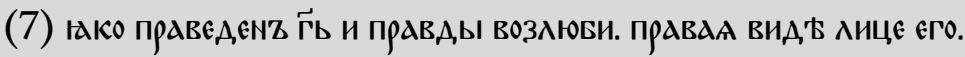
CAABA

(8) Boć sprawiedliwy pan / a sprawiedliwosic miłuie / vprzeymoṡc rado widżi oblicẑe iego. chwata

(8) Boć sprawiedliwy / a nic niema milssego nad sprawiedliwoṡc vprzeymośc rado widẑi oblicże iego.

Приведенное сравнение демонстрирует как факт обращения автора рукописи к тексту Библии Леополиты, так и характер внесенных изменений.

Внесенные в текст BL изменения можно классифицировать следующим образом: (1) сокращение текста (см. Таблииу 3); (2) изменение порядка слов в тексте (см. Таблииу 4); (3) изменение грамматических и синтаксических форм (см. Таблииу 5); (4) лексические замены; (5) новый перевод фрагмента текста (см. Таблииу 6). Чаще всего встречается комбинация замен. Лексические замены мы разберем отдельно, а ниже в таблицах приведем примеры всех остальных изменений, внесенных автором в польский текст Псалтири из Библии Леополиты.

Таблицза 3

\begin{tabular}{|c|c|c|}
\hline $\begin{array}{c}\text { цсл. текст ПсСА } \\
\text { [№ псалма, лист] }\end{array}$ & пол. текст ПсСА & Библия Леополиты \\
\hline $\begin{array}{l}\text { [ПсСА, 94, Л. 1460б.] ґако } \\
\text { КААХСА во Гн'Вв'Б МоєМ' }\end{array}$ & $\begin{array}{l}\text { iakom przysiagt } w \text { gniewie } \\
\text { moim }\end{array}$ & $\begin{array}{l}\text { [566] iakom przysiągł na ten } \\
\text { cżas gdym sie gniewał }\end{array}$ \\
\hline 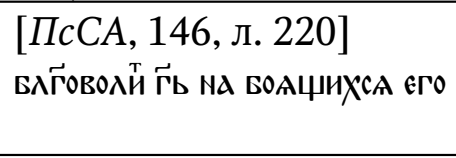 & $\begin{array}{l}\text { upodobanie pan̂skie iest } \\
\text { nad temi ktorzy sie boia go }\end{array}$ & $\begin{array}{l}\text { [588] upodobanie a kochanie } \\
\text { Pan̂skie iesth nad tymi co sie go } \\
\text { obawaią }\end{array}$ \\
\hline $\begin{array}{l}\text { [ПсСА, 31, л. 32] в потоп'ь } \\
\text { водZ многихъ }\end{array}$ & w potopie wod wielkich & $\begin{array}{l}\text { [538] w pothopie nawałnosici } \\
\text { wod wielkich }\end{array}$ \\
\hline
\end{tabular}

Таблица 4

\begin{tabular}{|c|c|c|}
\hline $\begin{array}{c}\text { цсл. текст ПсСА } \\
\text { [№ псалма, лист] }\end{array}$ & пол. текст ПсСА & Библия Леополиты \\
\hline $\begin{array}{l}{[П с С А, 43,540 б .] \text { А.ААZ }} \\
\text { єси нас ґаксо ОвЦа сн'В,и }\end{array}$ & $\begin{array}{l}\text { Dates nas iakoby owce na } \\
\text { pokarm }\end{array}$ & $\begin{array}{l}\text { [544] Dałes nas i na pokarm } \\
\text { akoby owce }\end{array}$ \\
\hline 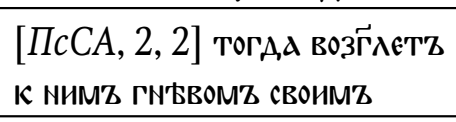 & $\begin{array}{l}\text { a tedy do nich mowic } \\
\text { budżie w gniewie swoim }\end{array}$ & $\begin{array}{l}\text { [527] a thedy w gniewie swoim } \\
\text { do nich mowić będzie }\end{array}$ \\
\hline $\begin{array}{l}\text { [ПсСА, 6, 4об.] гровъ } \\
\text { отверстZ гортань ихZ }\end{array}$ & $\begin{array}{l}\text { Grob otworzony iest gardto } \\
\text { ich }\end{array}$ & $\begin{array}{l}\text { [528] Garło ich iest iako grob } \\
\text { otworzony }\end{array}$ \\
\hline
\end{tabular}


Таблицуа 5

\begin{tabular}{|c|c|c|}
\hline $\begin{array}{c}\text { цсл. текст ПсСА } \\
\text { [№ псалма, лист] }\end{array}$ & пол. текст ПсСА & Библия Леополиты \\
\hline [ПсСА, 16, 13об.] оуслыши & wystuchay & [531] racż wysłyssec் \\
\hline 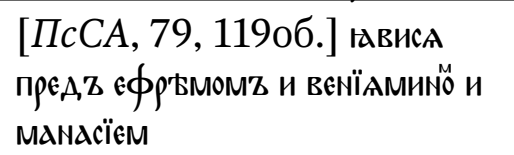 & $\begin{array}{l}\text { okaż sie przed ieffraimẽ } \\
\text { / beniaminem / } \\
\text { manassem }\end{array}$ & $\begin{array}{l}\text { [560] okaẑ sie przed Effraim/ } \\
\text { Beniamin y Manasse }\end{array}$ \\
\hline 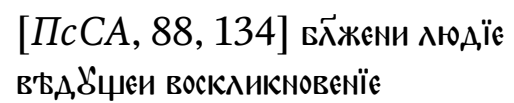 & $\begin{array}{l}\text { błogostawiony lud umie } \\
\text { spiewanie }\end{array}$ & $\begin{array}{l}\text { [563] błogosławiony lud ktory } \\
\text { umie chwałę (cżynic Panu) }\end{array}$ \\
\hline
\end{tabular}

\section{Таблица 6}

\begin{tabular}{|c|c|c|}
\hline $\begin{array}{c}\text { цсл. текст ПсСА } \\
\text { [№ псалма, лист] }\end{array}$ & пол. текст ПсСА & Библия Леополиты \\
\hline $\begin{array}{l}\text { [ПсСА, 34, 360б.] И НА МА } \\
\text { воДвесєАИШАСА }\end{array}$ & $\begin{array}{l}\text { oni naprzeciw mnie } \\
\text { vweselili sie }\end{array}$ & $\begin{array}{l}\text { [540] oni na złośc் mnie } \\
\text { wesela stroili }\end{array}$ \\
\hline 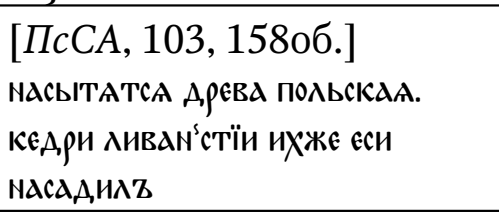 & $\begin{array}{l}\text { budu nasycone drzewa } \\
\text { polne y cedry Libanskie } \\
\text { ktore wßsžepit }\end{array}$ & $\begin{array}{l}\text { [569] przyċiągną k sobie } \\
\text { wilgośc் hoynie drzewa polne: } \\
\text { y Cedrowie Libaňskie kthore } \\
\text { wßcżepił }\end{array}$ \\
\hline $\begin{array}{l}{[\Pi c C A, 50,67] \text { ґако вєззаконїє }} \\
\text { моє АЗZ знаюо }\end{array}$ & boć ia znam złośc moie & $\begin{array}{l}\text { [547] Boć ia uznawam } \\
\text { sprosnośc nieprawości moiey }\end{array}$ \\
\hline
\end{tabular}

Особо следует отметить случаи “двойного” перевода цсл. текста, когда переводчик кроме переведенного текста в строке приводит еще один перевод над строкой. Такие пояснения могут касаться как польского текста (в этом случае над словами польского текста появляются пояснения на цсл. языке), так и цсл. текста (в этом случае пояснения на цсл. языке даются над словами цсл. текста, т. е. по существу происходит правка цсл.

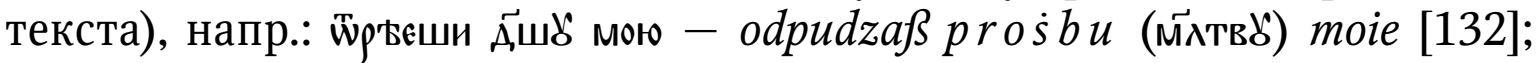

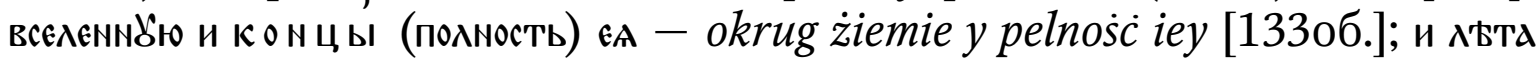

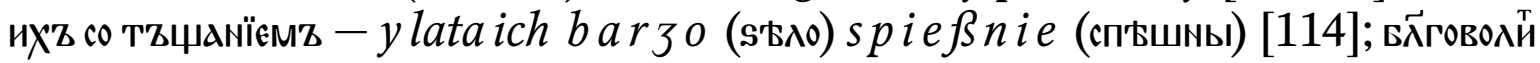

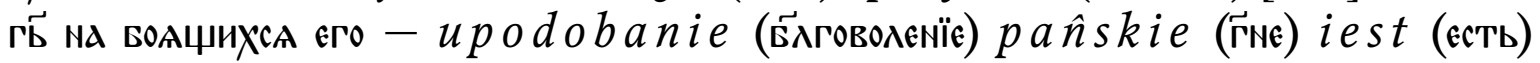
nad (наА) temi (тьвми) ktorzy (которые) sie boia (БоАтса) go [220] и др. Польский текст во всех этих случаях полностью взят из Библии Леополиты. Подобного рода “надстрочный” перевод встречается и в греческом тексте Псалтири, однако касается он только порядка слов, напр.:

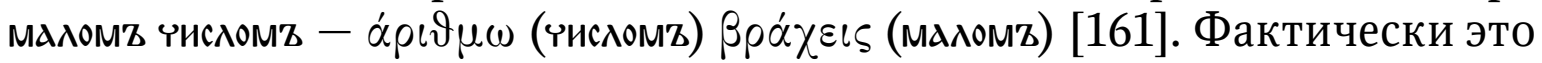
глоссы, но не на полях рукописи, а в тексте ${ }^{11}$.

11 Подобный способ глоссирования (не на полях, а в тексте) характерен также для интерлинеарной славяно-греческой Пс8 из собрания Московской духовной академии, также принадлежавшей Симону Азарьину [Пс8, л. 19об., 38об., 41 и др.]. 
Настоящее исследование рукописи ПсСА ставит перед собой задачу попытаться найти ответ на следующие вопросы: является ли рукопись ПсСА оригинальным произведением или списком с неизвестной нам рукописи, а также кем и с какой целью она была создана.

Исследователи библиотеки Симона Азарьина отмечают, что большая часть его рукописной коллекции состоит из произведений, переписанных в Троицком скриптории, и что у Азарина был свой личный писец [ОПАРинА 1998: 194-197]. На основании анализа и классификации почерков троицких рукописей были выявлены имена некоторых писцов троицкого скриптория первой трети XVII века [КЕдРов 1892: 11-14; Клосс 2012: 21-22]. Тем не менее рукопись ПсСА написана писцом, чей почерк не встречается в других рукописных книгах собрания Симона Азарьина, что неудивительно, так как рукопись написана на трех языках одним писцом. То есть писец должен был знать не только цсл. и греческий языки, что, вероятно, не являлось в XVII веке в православных монастырях большой редкостью, но и польский язык. То, что рукопись написана одним писцом, определяется не только визуально. Об этом свидетельствуют также некоторые описки, в частности, написание польской буквы в цсл. тексте. Таких описок всего три (написание слова серса ВМ. серца На Л. 82, ча囚А ВМ. чаша На Л. 107 и шсАкого ВМ. всакого ${ }^{12}$ На Л. 163), НО они красноречиво подтверждают тот факт, что рукопись писал один писец, хорошо владевший тремя языками. В рукописи довольно часто встречаются пропуски слов и словосочетаний, дополненные тем же писцом на полях книги, зачеркивания и исправления в тексте, не дописаны начальные буквы псалмов, что дает основания полагать, что перед нами оригинальное произведение, возможно, его черновой вариант. Об этом же свидетельствует замечание на полях рукописи [103], написанное латинскими буквами по-русски: dopisat izynoy psa. . . (окончание фразы не сохранилось, так как края рукописи были обрезаны, но текст можно восстановить как дописат(ъ) из иной псалтири, т. е. писец, он же автор, оставил для себя помету, предполагая позже найти в иной польской псалтири более точное соответствие цсл. тексту) ${ }^{13}$.

12 Написание буквы $w$ в начале этого слова можно было бы также интерпретировать как отражение белорусского произношения фонемы <в> как звука [y̆], что нам представляется менее правдоподобным, поскольку никаких других примеров такого произношения в тексте ПсСА нам не встретилось, в то время как замена букв была отмечена несколько раз. К тому же написание этой буквы в этом слове абсолютно идентично написанию польской буквы $w$ в этой рукописи.

13 Трудно сказать, какое именно место в 72-м псалме хотел уточнить переводчик. Весь польский фрагмент этого псалма на л. 103 взят из Библии Леополиты и является достаточно точным соответствием цсл. тексту. Возможно, автора не устраивал перевод следующей цсл. фразы: скотенъ Бы оу оу тєє - statem sie v ciebie. iako bydlu (в BL bidlę). 
Поскольку в Псалтири нет ни предисловия, ни послесловия, в которых могла бы содержаться информация о времени, цели, писце или авторе этого произведения, атрибутировать ПсСА приходится на основании косвенных данных, прежде всего языковых. Особенности цсл. и польского языков рукописи, а также возможные ошибки и описки ее писца могли бы помочь с определением, в частности, того, была ли рукопись написана на великорусской или же на западнорусской территории ${ }^{14}$.

Характеризуя цсл. текст рукописи ПсСА, следует прежде всего отметить его соответствие дониконовским текстам Псалтири. Даже беглое сравнение этого текста с текстом старопечатной Псалтири с восследованием, изданной в Москве в 1636 году и также принадлежавшей библиотеке Троице-Сергиевой лавры [Пс1636], обнаруживает почти полное текстуальное сходство. В то же время для ПсСА характерно то, что она не разделена на кафизмы ${ }^{15}$ и в ней нет однообразия в способе обозначения номера псалма. До 38-го псалма их нумерация встречается то в тексте (напр., псалмы 1-3, 6-8 и др.), то на полях (напр., 4, 5, 9, 10 и др.), то номер псалма вообще отсутствует (11 и 76), но начиная с 39-го псалма устанавливается постоянное место обозначения его номера - на полях рукописи. Это обстоятельство лишний раз свидетельствует о том, что анализируемая рукопись, скорее всего, является черновым вариантом задуманной триглотты.

Орфография цсл. текста ПсСА в целом соответсвует нормам первой половины XVII века, но наблюдается непоследовательность в

14 Сам факт наличия рукописи в библиотеке Симона Азарьина автоматически не является свидетельством того, что Псалтирь была создана в Троице-Сергиевом монастыре. Известно, что большая часть рукописного собрания Симона Азарьина была переписана в троицком скриптории [ОпАРинА 1998: 194], но определенная часть его библиотеки была пополнена за счет книг, поступавших в казну Троице-Сергиева монастыря, келарем и казначеем которого Симон Азарьин являлся с 1634-го по 1654 г. [КлитинА 1979: 302]. Так, например, несколько владельческих записей имеет рукопись Андр151 из его собрания. Как уже отмечалось, ПсСА имеет семь владельческих номеров, являющихся номерами монастырского учета, но, кроме вкладной записи Симона Азарьина, другие владельческие пометы в ней отсутствуют. Можно предположить, что Симон Азарьин был первым владельцем этой рукописной книги, но можно почти полностью исключить его авторство, поскольку почерк рукописи не совпадает с многочисленными автографами Симона Азарьина, оставленными им на рукописях своего собрания. Выше уже отмечалось, что ПсСА является черновым оригиналом задуманной трехъязычной Псалтири, из чего следует, что написана она самим автором. Для объективности все же следует отметить, что известные нам автографы Симона Азарьина представляют собой только скоропись на цсл. языке, а рукопись написана полууставом, греческим курсивом и польским готическим шрифтом, что не позволяет убедительно сравнить почерк рукописи с автографами Симона Азарьина.

15 Обозначены только две кафизмы: третья на л. 14 и двенадцатая на л. 128 , но и они надписаны только латинскими буквами: Kaphisma. 


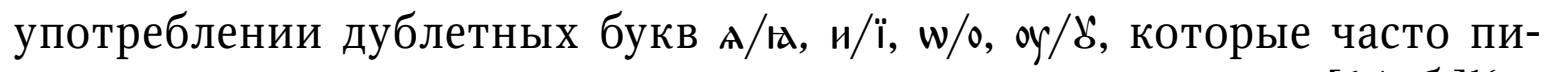
шутся в одних и тех же словах и позициях, напр.: ғавлюсн [14об.] ${ }^{16}$ и Авишаса [15об.], Азыкъ [17об. и др.] и ғазыкъ ${ }^{17}$ [18, 21об.], Амل [6], моюа

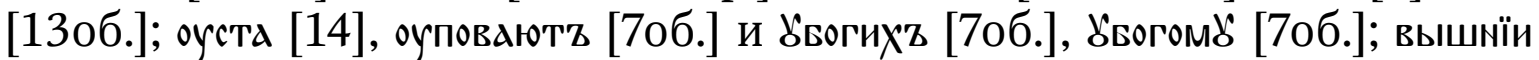
[7], пове $\lambda$ БмёємZ [50б.] и честин [60б.], презриши [80б.] и помнїши [60б.], имени [7] и ї А.бХХ [10], ми [5об.] И мї [14об.]; ороужїА [22], ОБЬАШа [14], ОААЕАИ [210б.] и шроужїа [14], шгнь [20об.]. Хотя в ПсСА всюду встречается написание ұаломz с буквой “пси”, так же последовательно слово псдлтырь пишется без этой буквы (напр., л. 32об.). Особое внимание следует обратить на многочисленные случаи написания буквы z вместо о в

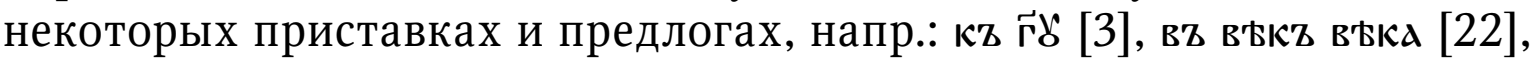

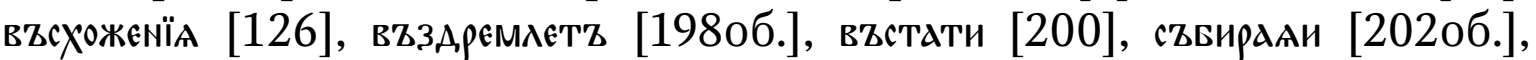
вZарб̈жєна [216], съв'ЪтZ [168об., буква z исправлена на о]. При этом нормой для рукописи всё же является написание буквы о в этой позиции (наПр., вознесиса, воспоємz, возваша, сотвори, соверши и др.), Что соответствует и печатной Псалтири с восследованием 1636 года. По наблюдениям Б. А. Успенского, написания предлогов и приставок с буквой z, а не с буквой о были ранее приняты в Московской Руси и соответствовали орфоэпической традиции чтения буквы z как о в предлогах и приставках сz, вz, кz и приставке въз, однако в XVII веке эта традиция была последовательно представлена главным образом в Юго-Западной Руси, где являлась нормой и была закреплена в грамматиках Лаврентия Зизания 1596 г. и Мелетия Смотрицкого 1619 г. В Московской Руси эта традиция начинает распространяться со второй половины XVII века в результате влияния книжной культуры Юго-Западной Руси на великорусскую книжную культуру [УСпенский 1997: 165-169]. Таким образом, случаи написания буквы z вместо о в приставках и предлогах можно интерпретировать двояко: во-первых, как отражение старого книжного произношения, и во-вторых, как югозопаднорусское влияние ${ }^{18}$. Характерно, что один раз нами было отмечено написание буквы ь вместо буквы є в слове вйчьство [217об.], что также соответствует старому книжному произношению буквы ь как [е] (о примерах написания буквы “ерь” в суффиксах -ьств- см.: [Успенский 1997: 169-170]).

16 Здесь и далее при цитировании ПсСА в скобках указываются листы рукописи.

17 Оба графических варианта Азыкъ и ґзыкъ могут употребляться в одном и том же значении: 'народ’ - пол. narod [17об., 18 и др.] или 'орган речи’ - пол. jezyk [210б., 56об. и др.].

18 Следует отметить, что подобные случаи написания буквы z вместо о в некоторых приставках и предлогах были нами отмечены также в двух уже упоминавшихся рукописных славяно-греческих Псалтирях XVII века из Троицкого собрания Пс8 и Пс9, напр., в Пс8: въскерни [19об.], възАювлю [20об.], въсташа [38об.] и др.; в Пс9: сътворй [5], въстахй [20], въ̆да [160б.] и др. Поэтому первое предположение нам кажется более вероятным. 
На фоне в целом правильного цсл. языка выделяются некоторые отклонения от нормы. Это, прежде всего, девять случаев цоканья: оцысти [24об., 68, 118об.], оцыститъ [6, 114об.], оцыстиши [84об.], оцыцаюющаго [1550б.], мє оцыститсл [173об.], оцыцєнাє [203]. Нельзя не заметить, что все примеры цоканья отмечены только в словах с корнем чист-. Весьма знаменательно, что аналогичные случаи встретились нам также в рукописной Пс8 (л. 35 шцысти, л. 101об. оцыстиши, л. 132об. оцыстй, л. 137 оцысти, л. 8 шцыстит - глосса к глаголу изостритz, л. 82 оцысти глосса к глаголу истрєви), причем все позиции с цоканьем, кроме последней глоссы, в обеих рукописях совпадают. В рукописи Пс9 те же формы встречаются во всех позициях, кроме одной [лл. 6, 25, 71, 92, 95, 133 и 158 $]^{19}$. Более того, написание форм оцысти / оцисти спорадически встречается и в других рукописях, созданных в Троице-Сергиевом скриптории ${ }^{20}$, что могло бы свидетельствовать в пользу того, что исследуемая нами рукопись была создана именно здесь.

Далее в цсл. тексте ПсСА нам встретилось три примера аканья (кальна [116], пдоучахбеса [138об.] и дрганы [208об.]), а также семь случаев написания русского ж вместо цсл. жА: въсүоженїА [126], прєжє [2020б.], оутверженїє [140б., 16, 27об.], оутвєржаєтz [40] и чюжїн [17об., там же: чюждїн]. Отметим также несколько примеров окончания -ого в Р. п. ед. ч. адъективного склонения: всакого [104, 115об., 163, 198об.] и єдиного [221об.], однако во всех этих случаях окончание -ого встретилось и в печатной Пс1636.

Как видим, цсл. текст рукописи, хотя и содержит определенные диалектные особенности, не позволяет с полной определенностью отнести ее автора и место написания к конкретной территории, однако дает основания предполагать, что рукопись могла быть написана в скриптории Троице-Сергиева монастыря.

Что касается польского текста ПсСА, то он предоставляет богатый материал для анализа. Как уже отмечалось, автор пользовался польским текстом Псалтири из Библии Леополиты в качестве подстрочника, часто оставляя его без изменения, но иногда внося изменения не только в его текст, но и в язык.

Пожалуй, самой яркой чертой польского языка рукописи является способ передачи носовых гласных. Несмотря на то, что автор пользовался печатным польским текстом Псалтири, в котором носовые гласные употребляются в соответствии с традициями польского языка того

19 Эти интерлинеарные славяно-греческие рукописи представляют собой списки с Псалтири Максима Грека 1552 г. [Вернер 2017: 41].

20 Так, написание оцысти / оциисти нам встретилось в двух рукописных Псалтирях с восследованием из собрания Московской духовной академии: в рукописи из библиотеки архимандрита Дионисия [Пс73, л. 69об.] и в Пс137 на лл. 6, 6об. (на л. 22 форма оцыстй). 
времени $^{21}$, эти буквы в исследуемой рукописи отсутствуют ${ }^{22}$. Судя по всему, автор некоторое время колебался в способе обозначения носовых гласных, так как в польском заглавии рукописи он использовал обозначение носового гласного с помощью двух букв, о чем свидетельствует написание KSENGA, а на том же первом листе рукописи встретилось также написание $b e^{n} d z i e$. Подобное обозначение носового гласного было использовано в рукописи еще только один раз: trombach [149об.] (BL trąbach). Так называемое разложение носовых гласных на два звука было весьма характерно для периферийного польского диалекта (polszczyzna kresowa), и многочисленные примеры такого написания исконных носовых гласных встречаются во многих документах и памятниках письменности XVI-XVII вв. [KuRzowA 1993: 82; KuRYŁowicz 2005: 2930]. В исследуемом памятнике такого рода написания исключительно редки - всего три случая, нормой же для ПсСА является употребление на месте носовых гласных $q$ и е в Библии Леополиты букв $u$ и $a$, напр.: muz [18] = męz, wugle [15] = węgle, ruce [25об.] = ręce, muka [13] = męka, wystupki [19] = występki, naucẑu [34об.] = naucżę, koronu [20] = koronę, luknie sie [26] = lęknie sie, rozráduiu sie y rozweselu sie [30] = rozráduię sie y rozweselę sie; $m u d r o \hat{c} \hat{c}$ [18об.] = mądrośc, $r u k$ [14] = rąk, sudy [16] = sqady, su [3] = są, wstupit [15] = wstapit, krug [33] = krąg, bacẑuc [38об.] = bacżac, mоcu [17об.]

21 В XVI в. в польской письменности использовалось несколько конкурировавших между собой орфографических традиций. В частности, наряду с печатными текстами с этимологически правильным написанием носовых гласных часто встречаются тексты, в которых вместо этимологического $е$ пишется буква $e$ (реже - вместо $q$ буква $a$ ), что является отражением деназализации носовых гласных в некоторых польских диалектах. Наиболее последовательно процесс деназализации отражается в написании возвратного местоимения sie как sie, которое присуще произведениям, изданным в большинстве польских типографий того времени [BuNčı́́ 2012: 235-236]. Для Библии Леополиты характерно этимологически правильное написание носовых гласных, однако возвратное местоимение пишется без носового - как sie.

22 Следует отметить, что иногда в рукописи встречается своеобразное написание буквы $а$ с небольшим хвостиком, уходящим под строку, которое мы не склонны рассматривать как носовую букву q по следующим причинам. Во-первых, если рассматривать такие написания как “ $а$ носовое”, то следует констатировать, что в подавляющем большинстве случаев написания с “носовым $a$ ” встречаются компактно и являются неправильными (напр., на л. 60: poddąt, mitowąt, на л.56: ą, twarz, pąnie, prąwie; на л.62: dąwa, mąmy, nąrodowie), что было бы по крайней мере странным, если учесть, что у автора рукописи был перед глазами печатный польский текст псалтири, орфографии которого он в остальном старался следовать. Во-вторых, написание буквы $а$ с таким же хвостиком время от времени встречается в греческом и даже в цсл. тексте, где носовых гласных быть не могло (напр., на лл.183об., 184об., 186, 190, 195 и др.). В-третьих, в рукописи почти не встречается написание буквы $\ell$, поэтому предположение, что “ $а$ с хвостиком” является носовой гласной, означало бы, что в польском тексте ПсСА встречается только одна носовая гласная, да и та не на месте. По-видимому, хвостик у буквы $a$ время от времени появлялся случайно в результате особенностей пера или почерка писца рукописи. 
= moca; we wnutrz [58] = we wnątrz; rozciagni [380б.] = rosc̈iagni, zados்̈i [39] = $\dot{z}$ ądości $i$, naciagnuli [83 об.] = naciągnęli, mowiac [37] = mowiąc, cẑynia [39] = cżynia, pode mna [17] = pode mna, przed miesiacem [990б.] = przed miesiacem, kwitnuc [142об.] = kwitnaci. Иногда такие манипуляции с носовыми гласными приводят к образованию непонятных слов, напр.: przekluci $i$ [185об.] (BL przeklęci), porzudki [150об.] (BL porządki), cẑusto [82, 202об.] (BL cżęsto), rzudzit [62] (BL rzadżit), porzudnie [64oб.] (BL porządnie), ruża [59об.], BL ręża).

Очевидно, что писец рукописи ПсСА, сознательно отказываясь от употребления специальных букв для носовых гласных в польском тексте, колебался в способе их обозначения на письме, поскольку в рукописи часто встречаются исправления на месте носовых гласных ${ }^{23}$, напр.: mudrosici [67об.] (и исправлено на $a$, BL mądrości $i)$, vwesele [IBID.] (e исправлено на $u$, BL vwesela), z toba [103] (а исправлено на $u$, BL z toba; при этом на л. 175 мы видим обратное исправление: в слове $S$ tobu u исправлено на $a$, BL $S$ thoba), $m \boldsymbol{u} \hat{z}$ [126] (u исправлено на $a$, BL $m a \dot{z} ;$; при этом на л. 176об. мы видим обратное исправление: в слове $m \boldsymbol{a} \hat{z} a$ исправлено на $u$, BL maz), lecucey [139] (и исправлено на $a$, BL lecacey), ziemie [150] (e в окончании исправлено на $u$, BL: ziemię), pragnacy [168] ( $а$ в суффиксе исправлено на $u$, BL pragnacy).

Зафиксированы также частые случаи деназализации гласного е, причем во всех позициях, напр.: ŝwiety [72] = święty, mie [72] = mię, iezyki [4об.] $=$ ięzyki, piniedzy [12] = piniędzy, ymie [19об.] = imię, wieżienie [71] = więzienie и др., а также несколько примеров деназализации гласного a: powstawaiocych [18] (BL powsthawaiacych), sosiadom [55] (BL sasiadom).

Все эти примеры свидетельствуют прежде всего о том, что в родном языке автора рукописи носовые гласные отсутствуют и что он довольно непоследовательно старался обозначать носовые гласные буквами $a, u$ или $е$.

Если случаи деназализации носовых гласных наблюдаются как в памятниках, написанных на исконной польской территории, так и в памятниках, отражающих периферийные диалекты [SICIŃSKA 2015: 204],

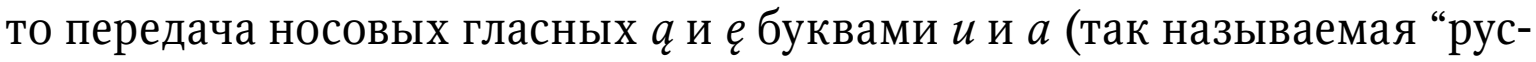
ская” реализация носовых гласных ${ }^{24}$ ) наблюдается, причем очень непоследовательно, только в памятниках, отражающих северный периферийный польский диалект и написанных в северо-восточных регионах

23 Для рукописи характерен следующий способ исправлений: писец, как правило, не зачеркивает исправляемую букву, а пишет над ней другую.

${ }^{24}$ Термин "ruska realizacja samogłosek nosowych" употребляется в работах польских исследователей в качестве обозначения одного из способов передачи носовых гласных в памятниках письменности, отражающих периферийный польский диалект [KuRZOWA 1993: 85; GREK-PABISOWA, MARYNiAKOWA 1997: 47]. 
Речи Посполитой [GReK-Pabisowa, Maryniakowa 1997: 47; KuRzowa 2006: 85; KuRYŁowiCZ 2005: 30; LUTO-KAMIŃSKA 2015: 33]. Способ передачи носовых гласных в ПсСА является, таким образом, весьма нетипичным именно своей последовательностью, которая проявляется в том, что польский текст Псалтири совершенно избавляется от носовых гласных. В результате этой самой значительной интервенции в польский язык ПсСА многие польские слова становятся похожими на русские (ср.: $p y$ ка, научу, поступки, вниду, трубы, зубы, голубица, внутрь, глубокость, на бубне, на работу свою и др.). В то же время некоторые польские слова с носовой гласной, у которых есть аналог в русском языке, переводчик модифицирует “нерусским” способом, напр.: cẑusto [82] (вм. *cżasto, ср. pyc. часто), porzudki [150об.] (вм. *porzadki, ср. pyс. nopядкu), swiety [72] (вм. *'swiaty, ср. рус. святой), madros்c [41об.] (вм. * mudrośc, ср. рус. мyдpость), w ymie [19об.] (вм. *imia, ср. рус. имя), iеzyki [4об.] (вм. *iazyki, ср. рус. языки), ogludam [16] (вм. *ogladam, ср. рус. глядеть), cẑustki [30об.] (вм. * $c z a s t k i$, эта форма также встречается, напр., на л. 83). Особенно часто такие нереализованные русские формы встречаются в окончаниях местоимений, напр.: radu twoie [19об.], wolu twoie [47об.], dußu moie [лл. 49об., 51, 75об.], prawdu swoie [75об.], wyrwu y uwielbie go [141], при этом следует отметить, что к концу рукописи именно они чаще всего написаны “правильно” (т. е. с окончанием $-u$ ) или исправлены.

Особенно ярким примером последовательной замены польских носовых гласных $е$ и $q$ буквой $и$ являются написание форм глагола быть (в пол. тексте инфинитив bydẑ на л. 4): budu вместо będę $e^{25}$ (напр., л. 71об., 72 и др.), budżiesz вместо będziesz (напр., л. 16), budżie вместо będzie (напр., л. 13, 29 и др.), budżiem [580б.] вместо będziem, budżiemy [106об.] вместо będziemy, budu вместо będq̨ (напр., л. 19), budż вместо bądź (напр., л. 26об.). Таким образом, исконно польские глагольные формы последовательно заменяются их западнорусскими вариантами. Отметим также, что для обозначения глагола $s q$ писец пользуется написанием $s u$.

Очевидно, что именно такой способ произношения польских носовых гласных присутствовал в том диалекте польского языка, которым владел автор анализируемой рукописи, и данные исследований позволяют вполне определенно указать на северо-восток Речи Посполитой Литву и Белоруссию. Так, Е. Ф. Карский писал о “странном явлении” в словарных полонизмах у белорусов, когда польские носовые гласные передаются через кириллические буквы $y$ и $a$ [КАРский 1903: 169]. Написание буквы $e$ на месте общерусского $a$ после мягкого согласного, отражающее белорусское произношение, отмечает Е. Ф. Карский во многих западнорусских памятниках письменности XV-XVII вв., написанных

25 Один раз на месте польского będę нами была отмечена форма bedu [14об.]. 
на “простой мове” 26 . В польском языке ПсСА, таким образом, получило отражение белорусское произношение польских носовых. Примеры де-

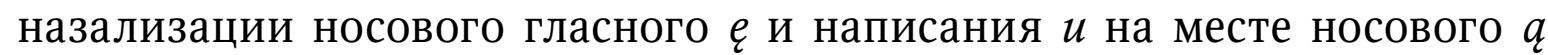
( $p u j d u, s$ tobu, sie) отмечаются в текстах на “простой мове” и другими исследователями [MOSER 2002: 50].

Отметим еще некоторые особенности польского языка ПсСА. В памятнике достаточно часто наблюдаются случаи замены буквы $h$ буквой ch, но только в трех словах: choyny, choynie (вм. hoyny, hoynie, напр., л. 42об.), na charfie (вм. na harffie, напр., л. 32об.) и zchanbion, pochaňbieni (вм. zhaňbion, pohanbieni л. 31, 35об.). Эти формы встречаются наряду с правильными написаниями с буквой $h$ (напр., лл. 118, 142, 141об. и др.). Отмечены также два случая обратной замены: написание niehay [198об.] вм. niechay и grzehi [310б.] вм. grzechy. Примеры подобных замен могут свидетельствовать о том, что автор рукописи не различал звонкий фрикативный $[\gamma]$ и глухой [ch]. Поскольку западнорусский язык различал эти звуки, случаи смешения букв $h$ и $c h$ достаточно редко фиксируются в памятниках западнорусской письменности этого времени [GREK-PABISOWA, MARYNIAKOWA 1997: 54; LUTO-KAMIŃSKA 2015: 36; KURYŁOWICZ 2005: 39]. Отмечено также несколько случаев написания $r$ на месте $r z$, напр.: odrucatem [16] вместо odrzucatem, chresciański [50об.] на месте chrzesciań$s k i$, а также случаи гиперкорректного написания $r z$ на месте $r$, напр.: grzyzła [93] вместо gryzła, na gorzu [116] вместо na gorę, trzesktat [144] вместо tresktat. Подобные примеры нередко встречаются в памятниках, отражающих периферийный польский диалект [SICIŃSKA 2015: 210-211].

Некоторые явления, связанные с диакритикой, трудно интерпретировать однозначно, поскольку их можно рассматривать как ошибки правописания (результат невнимательности или небрежности писца рукописи) или же как фонетическое явление, отражающее особенности произношения автора. Речь идет о написании букв $t$ и $l, n$ и $n$ и об обозначении мягких свистящих и шипящих с помощью надстрочных знаков. Следует отметить, что ошибки в написании диакритических знаков характерны для многих памятников польской письменности исследуемого периода, в том числе написанных на исконных польских территориях. Однако если в последних памятниках эти явления редки и интерпретируются исследователями как ошибки правописания, то подобные ошибки в памятниках, написанных в Юго-Западной Руси, исследователи, как правило, объясняют особенностями местного произношения [cM. SicIŃSKA 2015: 207-210; GREK-PABISOWA, MARYNIAKOWA 1997: 53-54; LUTO-KAMIŃSKA 2015: 36; KURYŁOWICZ 2005: 25, 37-38].

26 Среди приведенных им примеров отметим следующие: свєтого, глєдєли, єзыкъ, пьнєзи, присєгою [КАРСКИЙ 1908: 95-98]. 
В рукописи ПсСА много случаев, когда писец писал букву $l$ вместо буквы $t$, напр.: od zlego [41], widzialem [42], wiedlug [119], napelnieni [199об.], cialo [13], dales [17], z wesolym [59об.] и др. Однако часто встречается и обратное явление, когда вместо буквы $l$ мы находим написание $t$, напр.: tudżie [57, 89], Psatm [62], stuby [75], tudu [79], nałaztem [134oб.], nieprzyiaciet [135] и др. Встречаются также примеры с “забытой” диакритикой для обозначения мягких согласных, напр.: stonce [207] (BL ston̆ce), zchanbion [31] (BL zhan̆bion), prozby [180] (BL prożby), cien [215об.] (BL cien̆), panskie [3об.] (BL pañskie), błogostawienstwo [3об.] (BL błogostawien̆stwo), skoncẑenie [1910б.] (BL zkon̆cżenie), но значительно более часты случаи, когда диа-

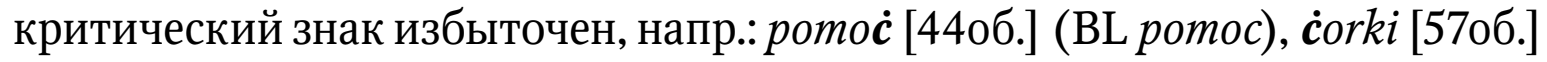

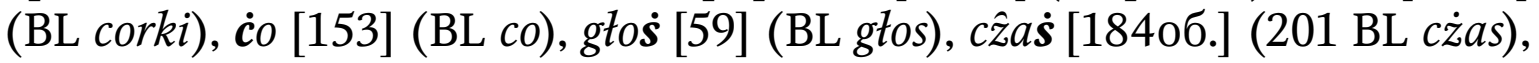
na ŝwitaniu [59] (BL na switaniu), o siwiadectwach [184] (BL o swiadectwach), $\dot{\boldsymbol{s}}$ wiadectwa [1910б.] (BL swiadectwa) и др. Следует отметить, что в целом писец относительно редко забывал написать диакритику для обозначения шипящих и мягких свистящих. При этом для обозначения буквы $\hat{z}[\check{z}]$ и диграфов $(c \hat{z}, d \hat{z}, r \hat{z})$ он использовал запятую над буквой $z$, для обозначения мягких свистящих $\dot{c}, \dot{s}, \dot{z}$ он пользовался точкой, а мягкость $n$ обозначал всеми возможными надстрочными знаками: “гачеком” $(\check{n})$,

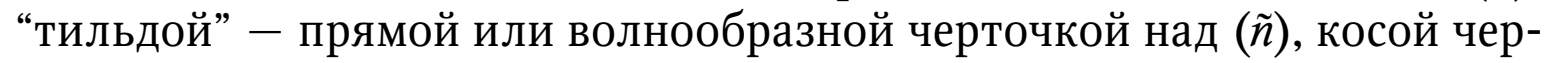
точкой $(\dot{n})$ или точкой $(\dot{n})$. Характерно, что такое использование диакритики сложилось не сразу, и на первых листах рукописи писец пользовался диакритикой Библии Леополиты, в которой точка над буквами $\dot{c}, \dot{s}, \dot{z}$ обозначала их мягкость, с помощью точки обозначался звук [ž], она использовалась в диграфах $c \dot{z}, d \dot{z}, r \dot{z}$, а для обозначения мягкого $\check{n}$ употребляется “гачек” или точка $(\check{n} / \dot{n})^{27}$.

Из фонетических особенностей польского текста ПсСА отметим еще редкие примеры мягкого $c h$ и $c \dot{z}$, которые проявляются написаниями chi и cżi: chiba [11] (BL chyba), chitrze [162] (BL chytrze), cżinili [55, 164об.] (BL cżynili), а также случаи смешения букв $i$ и $y$, напр.: samy [18об.] (BL sami), sprawi [18] (BL sprawy), tis [20] (BL tyś), broni [23об.] (BL brony), cali [74об.] (BL caty), wżiely [84об.] (BL wzięli), ygrzysko [118] (BL igrzysko), $\dot{c} y \S 3 y$ [39об.] (cissy), 3wiç̧ay [188] (BL zwycżay), dtugiemy [219] (BL dtugiemi), rozmnoẑyli sie [48] (BL rozmnożyty sie), skarbi [450б.] (BL skarby) и др. Последнее явление встречается в памятниках письменности рассматриваемого периода, отражающих как мазовецкий, так и северный периферийный диалект польского языка [KURYєOWICZ 2005: 33-34]. Имеется

27 Общих орфографических правил в польском языке XVI-XVII вв. еще не было, поэтому исследователи отмечают большое разнообразие в орфографии печатных и рукописных произведений этого времени, в частности, в написании диакритики [BUNČIĆ 2012: 220, 231-240]. 
также несколько примеров написания буквы $y$ вместо $i$ после предлогов (напр., $w$ ymie л. 19об.), что также было характерно для западнорусских памятников письменности [КАРский 1908: 263-264].

Интересно, что в памятнике не засвидетельствованы случаи написания буквы $y$ вместо $i$ после $r$, а также после шипящих и $c$. Такие написания были характерны для памятников западнорусской письменности и отражали твердое белорусское произношение звуков [р], [ч], [ж], [ш], [щ] и [ц] [КАРский 1908: 261-262]. Исключением является встретившееся несколько раз написание morze cẑyrwone [164об., 165об.] (BL cżerwone).

Об особенностях произношения автора рукописи, в частности о мягком произношении $e$ [је] в некоторых словах, свидетельствуют написания: z iegipta / z iegyptu [120/178] (BL z Egyptu), w iegypcie [лл. 164об., 165об., 206] (BL w Egyptcie), iedomskie [2080б.] (BL Edomskie), panienki [221об.] (BL panenki), Izraielu [107об.] (BL Israelu), wiedtug [119, 188об.] (BL wedtug). К особенностям произношения можно также отнести написание Angioty [157oб.] (BL Anioty), а отражением аканья считать следующие два примера: sieratámi [173] (BL sirothami) и raspacẑat [38об.] (BL rospacizat).

Интересной графической особенностью польского текста рукописи является частое использование знака “тильда” (волнообразная, но чаще почти прямая горизонтальная черта) над гласными для обозначения выносных согласных $m$ или $n$. Напр., $\tilde{o}=$ on, om: zchanbiõ [29об.], potõstwo [22], skrõne [24об.], nieprzyiacielõ [29] и др.; $\tilde{e}=$ en, em: o testamécie [24об.], cẑłowiecẑẽstwa [290б.], wołałẽ [15], iest pañ̃ [23], odẽnie [29] и др.; $\tilde{l}=$ in, im:

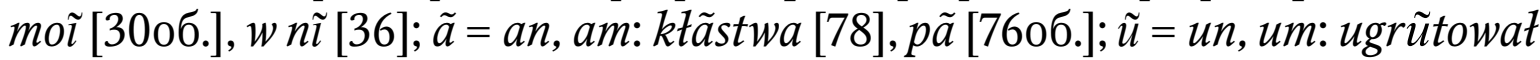
[23] и др. Эти написания встречаются во всех позициях (в конце слова, в окончании, на стыке слов) и не находят поддержки в тексте Библии Леополиты. Знак “тильда” в этой функции широко использовался в средневековых текстах, написанных на латинском и некоторых других языках, в том числе в книгах на польском языке, изданных в Литве [LuToKAMiŃSKA 2015: 30; SEMKOWCZ 1951: 474]. Использование “тильды” свидетельствует о знакомстве автора рукописи с книжностью на польском и латинском языках.

Что касается морфологии польского текста ПсСА, то она в целом оставлена без изменений, а немногочисленные случаи замены грамматических форм непоследовательны и не меняют “польского” облика текста ${ }^{28}$.

${ }^{28}$ Из наиболее значительных можно отметить частые случаи изменения грамматической формы существительного в польской конструкции na wiek(i) wiekom на конструкцию na wiek(i) wiekow, которая соответствует вовъкъ въка или вовљки цсл. текста Псалтири [57, 70, 80об. и др.]. 
В целом без существенных изменений сохранен в польском тексте ПсСА и синтаксис Библии Леополиты. Из синтаксических замен отметим только непоследовательную замену словом ktory слова со в придаточных предложениях, напр.: nad temi ktorzy sie boia go [156] (в BL: nad temi co sie go boią; цсл. на вонацихса єго), ktory snopki znosii [202об.] (в BL: co snopki znosii; ЦСЛ. рӦкоАти сZБираАИ).

Выше уже отмечалось, что одним из способов изменения текста польского источника ПсСА является замена некоторых слов. Из многочисленных лексических замен следует прежде всего отметить последовательную замену слова kościot словом cerkiew [4, 24, 25 об., 26 и др.], слова krześciański словом chržesciański / chresciański [4, 22об., 50об., 79 и др.] и слова krystus словом chrystus [6, 13, 19об., 20об., 49 и др. $]^{29}$. Поскольку эти замены осуществляются автором рукописи последовательно, можно судить, что он придавал этим словам особое значение. Слово kościoł и его производные в польском тексте рукописи не встретились ни разу, вместо него последовательно употребляется слово cerkiew. Согласно словарю польского языка С. Линде, это слово в старопольском языке имело значение “православная церковь”: "koścół szczególniey Greckiego obrządku” [LINDE 1807, 1.I: 227], в то время как слово kościot "tylko katolikom służyć może" [LiNDE 1808, 1.II: 1094]. Эта замена весьма показательна для определения адресата анализируемого памятника письменности.

Остальные лексические замены, хотя и многочисленны, однако не столь последовательны. Некоторые из них даны в Таблище $7^{30}$ :

Таблициа 7

\begin{tabular}{|c|c|c|c|}
\hline лист ПсСА & цсл. текст ПсСА & пол. текст ПсСА & Библия Леополиты / стр \\
\hline $110 б$. & Бє3ठัМЕNZ & głupi & niemądry / 531 \\
\hline 25 & $\tilde{\omega}$ Б'ВАZ & z potrzeb & z nędzy / 536 \\
\hline 164 & ВZ БЛГГОВОЛЕКїИ & w ulubieniu & w dobrey woley / 570 \\
\hline $250 б$. & БААГОАБПП̈є & ochudaẑnosc & pięknos்c / 536 \\
\hline 173 & ВзЬщц & ßperuie & rumował / 573 \\
\hline 13 & вид'ВТТ & ogladac் & obezrzec் / 531 \\
\hline 145 & ВоЗВЕСЕАИША & uweseliły & rozradowały / 566 \\
\hline 30об. & в воздыххамїихъ & w łkániu & w płacżu / 538 \\
\hline $1450 б$. & B03рАА, С'ЕMCA & raduymy sie & weselmy sie / 566 \\
\hline 173 & восХитА & rozßarpaia & rozdarli / 573 \\
\hline
\end{tabular}

29 Эта замена осуществляется также в однокоренных словах, напр.: chrystusowy вместо krystusowy [12об., 14об., 56 и др.], antychrystowych вместо Anthykrystowych [69].

30 Слова в таблице приводятся в алфавитном порядке цсл. слов и даются в формах, встретившихся в тексте ПсСА. 


\begin{tabular}{|c|c|c|c|}
\hline лист ПсСА & цсл. текст ПсСА & пол. текст ПсСА & Библия Леополиты / стр. \\
\hline 11 & врагZ & nieprzyiaciel & przeciwnik / 530 \\
\hline 124об. & гнон & plugastwo & smiecii / 561 \\
\hline 40 & грьшмїцы & grzesznicy & złossnicy / 541 \\
\hline 11 & A,OKOA't & dokudẑe & pokieyże / 530 \\
\hline 113об. & жикичъ & namieciech & mießkaniach / 558 \\
\hline 126 & 3АКОNZ АААИ & zakonudawca & sprawca zakonu / 561 \\
\hline 25 & Nе измемогё & nie osłábieiu & nie ustąpiłem / 536 \\
\hline 29 & ИСПОВ'ВАААТТЕ & wyznáwaycie & chwalcie / 537 \\
\hline $790 б$. & KOHOBD & garniec & garnek / 550 \\
\hline $240 б$. & КРОТКИА & skrõne & ciche / 536 \\
\hline 78 & $\lambda * \lambda$ & kłãstwa & lży / 550 \\
\hline 810б. & Аживи & kłamliwi & fałecżni / 551 \\
\hline 33об. & Во МNOЖЕсTВ' & w okwitoṡci & w hoynoṡci / 539 \\
\hline 22 & NACDITATCA & budu násyceni & będą nakarmieni / 535 \\
\hline 24 & МЕВ'ЖЖествИА & nieumieietnos $\dot{c} i$ & niedbałos̀ci / 535 \\
\hline 102 & меПравА, С & nieprawos் & niecnotę / 556 \\
\hline 68 & МЕчеСТИВїн & niepoboẑni & niewierni / 547 \\
\hline $630 б$. & ОБЕТШАЕTZ & starze & zgrzybieie / 546 \\
\hline 212 & окрОУЖЕнїА & kruẑenia & obthocżenia / 585 \\
\hline $160 б$. & ОчИ & ocẑy & wzrok / 532 \\
\hline 104об. & WCKOPAOMZZ & toporem & nasiekiem / 556 \\
\hline 213 & не พ̈ими & nie odłucẑay & nie zgladzay / 585 \\
\hline $150 б$. & ẄкрышасA & odkryły sie & ukazáły sie / 532 \\
\hline 139 & ПлєщМА & barkami & ramiony / 564 \\
\hline $1530 б$. & плоти & ciała & mięsa / 568 \\
\hline 70 & Помоцмика & spomoẑycielem & spomocnikiem / 547 \\
\hline 141 & ПоПерєши & podepceß & potłocżyß / 565 \\
\hline 91 & Прєдвариша & uprzedžiły & przedeszli / 553 \\
\hline 158 & $\Pi p \in A, \mathrm{~B} \lambda \mathrm{Z}$ & granicu & cżyl / 569 \\
\hline $1930 б$. & пригвоздии & przebodẑ & zkol / 578 \\
\hline 184oб. & призрно & przebacẑu & przeglądnę / 576 \\
\hline 198 & пришє АьствовА & mießkała & pielgrzymowała / 580 \\
\hline 185 об. & пришАєцZ & obywatel & przychodzieň / 576 \\
\hline 610б. & прїим'Вте & obłapcie & rozmiłuycie sie / 546 \\
\hline 165 & прогн'Вваша & rozdraẑnili & rozżarzyły / 571 \\
\hline 19об. & прошєнÏА & prożby & żądoṡċi / 534 \\
\hline 290б. & в радоость & w rádość & w wesele / 537 \\
\hline
\end{tabular}




\begin{tabular}{|c|c|c|c|}
\hline лист ПсСА & цсл. текст ПсСА & пол. текст ПсСА & Библия Леополиты / стр. \\
\hline $1210 б$. & PA_АНитесА & rozraduycie sie & rozweselcie sie / 560 \\
\hline $1360 б$. & расхичаху & szarpali & darli / 564 \\
\hline 99об. & pö́no & welnu & runo / 555 \\
\hline 104об. & сВ'ТТило & sंwiatnicu & kościoł / 556 \\
\hline 18 & И С'ВМЕNИ ЕГО & y potomstwu ie $\mathrm{e}^{\mathrm{O}}$ & y plemieniu ie $\mathrm{ie}^{\mathrm{o}} / 533$ \\
\hline 15 & смутишасА & záburzyły sie & rozsypáły sie / 532 \\
\hline 56 & спиши & drẑymieß & zasypiaż / 544 \\
\hline $640 б$. & сOEер'BTE & zgromadzaycie & zbieraycie / 546 \\
\hline $710 б$. & сСААИ ми & osudẑ mie & wybaw mię / 548 \\
\hline 145 об. & сઠீшชో & sußu & ziemię / 566 \\
\hline 193об. & OYBOAXCA & ułukł & obawał / 578 \\
\hline 95 & $(A, \lambda)$ оузрАтв & patrzayciie & weyzrzycież / 554 \\
\hline 41 & OYКАОNИСA & odwroc sie & uchyl sie \\
\hline 97 & $\ddot{w}$ чр $е$ в & z ẑywota & $\mathrm{z}$ brzucha / 555 \\
\hline $2110 б$. & ІАА,Z АспнА,ИNZ & iad zmijowy & iad gadziny / 585 \\
\hline
\end{tabular}

Из таблицы видно, что некоторые лексические замены были обусловлены цсл. текстом Псалтири, однако достаточно часто переводчик следует собственным языковым принципам, заменяя польское слово равнозначным ему синонимом. Все эти слова встречаются в словарях польского языка XVI [SŁP XVI] и XVII-XVIII вв. [SŁP XVII] ${ }^{31}$. Следует отметить, что некоторые из них фиксируются словарем белорусского языка НосовичА [1870] $]^{32}$, но при этом либо совсем отсутствуют в “Словаре русского языка XI-XVII вв.”, либо впервые встречаются в памятниках письменности XVII в. [СлРЯ XI-XVII] ${ }^{33}$. Следует также подчеркнуть полное отсутствие как в цсл., так и в польском тексте ПсСА диалектной лексики ${ }^{34}$.

${ }^{31}$ Имеются в виду слова, написанные в соответствии с орфографическими правилами польского языка, напр. świq̨tnica, ogladać, namięć, zakonodawca и др.

32 Это слова облапиць, згромажаць, спомогащь, мюшкащь 'проживать', оглядащь 'осматривать', забуриващь 'разрушать', лкащь 'глотать', плюгавство 'дрянь, мерзость', улюбищь, разшарпащь 'разорвать'.

33 В XVII веке в великорусских памятниках письменности впервые встречаются следующие слова из приведенного выше списка: облапление, мпшкати, оглядати, плюгавство. В большинстве своем эти слова пришли в русский язык из польского через посредство западнорусского (старобелорусского) языка.

${ }^{34}$ Наблюдения над лексикой ПсСА могли бы стать предметом самостоятельного исследования. В рамках настоящей работы нас в первую очередь интересовал факт замены польского слова из Библии Леополиты другим, но тоже польским словом, встречающимся в памятниках письменности на польском языке и зафиксированным словарями польского языка XVI-XVII веков. 
Подводя итоги наблюдениям над особенностями польского языка ПсСА, можно отметить следующее: несмотря на то, что в распоряжении автора была польская Псалтирь из Библии Леополиты, он частично изменил не только текст, но и язык источника. Критика текста состояла в стремлении максимально точно передать на польском языке цсл. текст Псалтири. Языковые изменения касались прежде всего фонетики (главным образом носовых гласных) и частично словарного состава. В польском языке рукописи получили отражение некоторые фонетические черты, свойственные северному периферийному диалекту, однако самые яркие фонетические черты белорусского языка (такие как твердые [р], [ч], огубление твердого [л], аканье) практически не отразились ни в польском, ни в цсл. языке памятника. Некоторые языковые особенности польского текста ПсСА (прежде всего "русский” способ передачи носовых гласных) сближают его с текстами, написанными на "простой мове”, однако отсутствие характерных для “простой мовы” лексических белорусизмов, а также чисто польская морфология и синтаксис позволяют нам считать польский язык ПсСА образцом одной из его западнорусских диалектных разновидностей ${ }^{35}$.

Таким образом, суммируя данные анализа цсл. и польского языков ПсСА, можно почти полностью исключить вероятность создания рукописи на западнорусской территории. Более того, некоторые косвенные данные наводят на мысль о возможности создания триглотты в ТроицеСергиевом монастыре. Это, во-первых, интерлинеарный характер оформления текста, свойственный также двум славяно-греческим псалтырям, переписанным несколько ранее в Троицком монастыре (в западнорусских двуязычных аналогах тексты обычно писались параллельно в двух колонках). Во-вторых, определенное сходство в оформлении глосс, когда пояснение (вариант перевода) слова дается интерлинеарно - над поясняемым словом. В-третьих, совпадение в одних и тех же позициях примеров цоканья, которое заставляет задуматься над вопросом, не является ли одна из славяно-греческих рукописей протографом ПсСА. Однако даже поверхностное текстологическое сравнение обнаруживает определенные различия между рукописями Пс8 и Пс9, восходящими к

35 Отличие польского языка ПсСА от написанных кириллицей текстов на “простой мове” можно наглядно продемонстрировать путем сравнения двух образцов перевода одного и того же текста Псалтири: из ПсСА и из приведенного Е. Ф. Карским отрывка западнорусской Псалтири XVII в. на "простой мове" [КАРский 1908: 72]. Сp.: Rzekt pan panu memu. siadẑ na prawicy moiey. Aẑ́ potoẑe nieprzyiacioty twoie podnožkiẽ nog twoich. Rozgu moci twoiey wypuŝci p. z Syonu. panuiz wposirzodku nieprzyiaciot twoich [ПсСА, л. 175, псалом 105, л. 175] - и Рекс панz пану

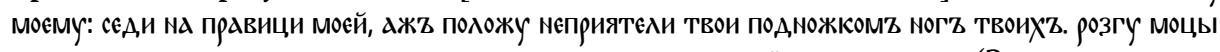

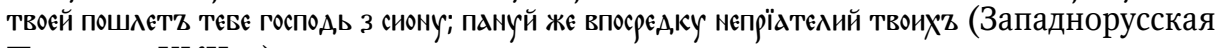
Псалтирь XVII в.). 
переводу Максима Грека, и рукописью ПсCA ${ }^{36}$. Если также учесть, что греческий текст в Пс8 и Пс9 написан кириллицей (т. е. в фонетической транскрипции), в то время как в ПсСА он написан греческим курсивом, можно говорить скорее о близости установок, но не о близости цсл. и греческого языков этих рукописей.

Выше уже отмечалось, что рукопись, по-видимому, представляет собой оригинальное произведение, скорее всего, его черновой вариант. В этом случае писец ПсСА одновременно являлся ее автором, о котором можно сказать, что он прекрасно владел тремя или четырьмя языками (цсл., греческим, польским и латинским) и, скорее всего, был выходцем из Юго-Западной Руси, где, вероятно, и получил образование в одной из братских школ ${ }^{37}$. Троице-Сергиев монастырь являлся в XVI-XVII вв. одним из крупнейших культурных центров Московской Руси, в котором обитало около 300 монахов [НиколАЕВА 2000: 157], в том числе - выходцев из Литвы, Белоруссии и Украины. Возможно, один из них и был автором анализируемой рукописи ${ }^{38}$.

Что касается причин и цели создания триглотты, то на этот счет в самой рукописи нет прямых указаний, но проведенное исследование позволяет выдвинуть определенную гипотезу. Текстологические и некоторые языковые данные свидетельствуют о том, что Псалтирь, в том числе ее польская часть, была предназначена православным христианам (ярким свидетельством этого является как пояснение на л. 3об. рукописи о правилах византийского обряда богослужения - необходимости чтения молитвы на “славах", так и последовательная замена в польском тексте ПсСА слова koscioł словом cerkiew). Сильное вмешательство

36 Сравнение цсл. и греческого текстов трех псалтирей из Троицкого собрания не являлось предметом настоящего исследования. Мы говорим о текстологических отличиях на основании сравнения не всего текста, а только отдельных его фрагментов.

37 Как в православных, так и в униатских братских школах Юго-Западной Руси изучались цсл., греческий, польский и латинский языки [ЦЕлуновА 1998: 59-64].

38 Не беремся строить безосновательных предположений, кто именно был автором ПсСА, но нельзя не отметить, что на эту роль подходил бы и сам владелец рукописи - Симон Азарьин. В его образованности не приходится сомневаться. Прямых указаний на то, что Симон Азарьин владел греческим языком, не сохранилось, но косвенно об этом может свидетельствовать наличие в его келейной библиотеке книг на греческом языке (кроме уже упоминавшихся псалтирей, это №№ 52, 72, 75 и 76 по каталогу монастырского учета 60-х гг. XVII в. [КлитинА 1979: 310-311]). Польские книги в его книжном собрании (по каталогу это №№ 20, 92-95 [IBID: 309, 312]) могли бы подтверждать его знание польского языка. Польский язык он мог изучить, находясь в имении княжны Мстиславской, род которой являлся потомками Гедиминовичей. В ТроицеСергиевой обители в первой половине XVII в. были и другие образованные люди, владевшие языками. Например, келарь Троицкой обители Арсений Суханов получил образование в одной из западнорусских братских школ и прекрасно владел цсл., греческим, польским и латинским языками. 
в фонетическую структуру польского языка, проявившееся прежде всего в фактическом “устранении” из нее носовых гласных, дает основание предположить, что адресатом ПсСА являлись жители (или житель) восточной части Речи Посполитой, для которых было привычным именно такое произношение польских слов с носовыми гласными. Чисто гипотетически можно предположить, что ПсСА предназначалась либо для униатов, возвращавшихся в православие, либо для католиков, проходивших обряд перекрещивания.

Известным борцом с католической и униатской “ересью” был в начале XVII в. патриарх Филарет, келейником которого служил одно время Симон Азарьин. При патриархе Филарете в 1620 г. на заседании церковного Собора были приняты правила чиноприема в православие католиков, униатов и православных из Литвы и Польши, а также в 1628 г. запрет на распространение в Московской Руси книг “литовской” печати. Хотя русские духовные власти поддерживали миграцию из Речи Посполитой, однако при переходе выходцев из Юго-Западной Руси на русскую службу их полагалось перекрещивать [ОпАРина 1998: 58-65]. Сохранились многочисленные свидетельства современников о том, что в конце XVI - XVII вв. знание цсл. языка в Юго-Западной Руси было недостаточным и что даже православные священники, не понимая цсл. книг, вынуждены были обращаться к книгам на польском языке [КАРСКИй 1903: 140-143; MARTEL 1938: 68-72; УСПЕНСКиЙ 2002: 405-406] ${ }^{39}$. Польский язык стал основным для западнорусской шляхты, по-польски писали не только униатские (Ипатий Потей, Лев Кревза и др.), но и православные культурные деятели Юго-Западной Руси (например, Мелетий Смотрицкий) [ЦЕлуновА 1998: 91-97]. Именно для выходцев из восточных земель Речи Посполитой, плохо понимавших цсл. язык, могла предназначаться трехъязычная псалтирь, в которой польский текст был нужен именно для того, чтобы будущий пр а в осл а вны й верующий понимал це рковносл ав янски й язык богослужения. Греческий язык в этом случае был использован для придания высокого статуса цсл. языку и должен был демонстрировать “истинность” и конфессиональную “правильность” цсл. текста. И не случайно эта Псалтирь оказалась в книжном собрании Симона Азарьина, который, несмотря на запрет патриарха, собирал и давал указания переписывать произведения

39 Приведем хорошо известное высказывание иезуита Петра Скарги, который в своем труде "O iedności kościoła Bożego pod iednym pasterzem" так характеризует современное ему западнорусское духовенство: “inż go [цсл. язык. - Е. Ц.] teraz prawie nikt doskonale nie rozumie. Bo tey na świecie nacyey nie masz, ktora by im tak, iako w księgach iest, mowiła; a swych też reguł, grammatyk y kalepinow do wykładu niema, ani iusz mieć może. Y stąd popi waszy, gdy co w Słowieńskim chcą rozumieć, do Polskiego się vdać po thumaczstwo muszą; abo więc tylo vsty a w czytaniu doktormi są. Y inney szkoły chyba na czytanie nie mai” [РИБ VII: 486]. 
украинско-белорусских авторов различных вероисповеданий [ОПАРинА 1998: 197]. В его библиотеке были не только полемические книги представителей киевской метрополии, но и произведения авторов, против которых эта полемика была направлена. Замечательно в этой связи то, что среди прочих рукописных книг в его коллекции находится "Книга приходящихъ от розныхъ въръ” [Чин188]. Наличие в книжном собрании Симона Азарьина книги о чинах принятия в православие говорит о том, что проблематика перекрещивания была ему интересна и небезразлична, в силу чего он вполне мог заказать перевод на польский язык цсл. псалтири, чтобы помочь новообращенным участвовать в православном богослужении. Это вполне соответствовало его установкам защитника православной веры.

\section{Библиограсрия}

Сокращения

МДА - Московская духовная академия

МК - Музей книги

ОР - Отдел рукописей

РГБ - Российская государственная библиотека, Москва

STSL.RU - электронные копии рукописей и старопечатных книг на сайте ТроицеСергиевой лавры (http://old.stsl.ru/manuscripts/; последнее обращение: 25.12.2017)

\section{Источники (рукописные и старопечатные книги)}

\section{Андр151}

ОР РГБ, ф. 304. I (Главное собрание библиотеки Троице-Сергиевой лавры), № 151 , Книга глаголемая Андриятис Иванна пресвятаго, архиепископа Константинограда, Златоустаго (STSL.RU).

$\Pi c C A$

ОР РГБ, ф. 173.I (Фундаментальное собрание библиотеки МДА), № 10, Псалтирь на славяно-греческом и польском языках (STSL.RU).

$\Pi c 8$

ОР РГБ, ф. 173.I (Фундаментальное собрание библиотеки МДА), № 8, Псалтирь славяногреческая (STSL.RU).

$\Pi c 9$

ОР РГБ, ф. 173.I (Фундаментальное собрание библиотеки МДА), № 9, Псалтирь славяногреческая (STSL.RU).

$\Pi c 73$

ОР РГБ, ф. 173.I (Фундаментальное собрание библиотеки МДА), № 73, Псалтирь с восследованием (STSL.RU).

$\Pi c 137$

ОР РГБ, ф. 173.I (Фундаментальное собрание библиотеки МДА), № 137, Псалтирь с восследованием (STSL.RU). 


\section{$\Pi c 1636$}

МК РГБ, фонд IV, № 459, Псалтирь, Москва, 1636 (STSL.RU).

$\Pi c 1715$

МК РГБ, фонд III, № 51, Псалтирь, Киев, 1715 (STSL.RU).

Чин188

ОР РГБ, ф. 173.I (Фундаментальное собрание библиотеки МДА), № 188, Чинопоследование соединяемым из иноверных к православной кафолической восточной иеркви (STSL.RU).

$B L$

Biblia to iest Kxięgi Stharego y Nowego Zakonu na Polski ięzyk z pilnośćiq wedtug Lácinskiey Bibliey od Kośćiołá Krześciáńskiego powssechnego przyięthey, nowo wytożona, w Krakowie w Drukarni Scharffenbergerów, 1561 (цит. по интернет-изданию электронной фотокопии на сайте https://www.polona.pl/item/11633395/526/; последнее обращение: 25.12.2017).

B63

Biblia święta, tho iest, Księgi Starego y Nowego Zakonu, właśnie z Żydowskiego Greckiego

y Łacińskiego, nowo na Polski ięzyk, z pilnościa y wiernie wyłożone, Brześć Litewski, 1563 (доступна в электронной фотокопии на сайте http://www.wbc.poznan.pl/; последнее обращение: 25.12.2017).

B72

Biblia to iest księgi Starego y Nowego przymierza znowu zięzyka Hebrayskiego / Greckiego y Eacińskiego na Polski przetożone, 1572 (доступна в электронной фотокопии на сайте http:// www.wbc.poznan.pl/; последнее обращение: 25.12.2017).

B99

Biblia to jest Księgi Starego y Nowego Przymierza wedtug Łacińskiego przekładu starego, w kościele powszechnym przyjętego, na Polski ięzyk z nowu z pilnościa przełożone, z doktadaniem textu Żydowskiego y Greckiego, y z wykładem Katholickim, trudnieyszych miejsc, do obrony wiary swiętej powszechnej przeciw kacerstwóm tych czasów należacych, przez D. IAKUBA WUYKA Z WĄGROWCA, Theologa Societatis Iesu, Kraków, 1599 (доступна в электронной фотокопии на сайте http://www.wbc.poznan.pl/; последнее обращение: 25.12.2017).

$P R$

Psałterz Dawidów, który snadźjest prawy fundament wszystkiego pisma krześcijeńskiego, 1548 (доступна в электронной фотокопии на сайте http://www.wbc.poznan.pl/; последнее обращение: 25.12.2017).

$P V$

Żottarz Dawidow przez mistrza Walentego Wróbla z Poznania na rzecz polska wytożony, Kraków, 1539 (доступна в электронной фотокопии на сайте http://www.dbc.wroc.pl/; последнее обращение: 25.12.2017).

P1532

Psałterz albo koscielne spiewanie / Krola Dawida /: nowy pilnie przełożony / z łacinskiego ięzika w polski / wedtug szczerego textu, Kraków, 1532 (доступна в электронной фотокопии на сайте http://www.jbc.bj.uj.edu.pl/; последнее обращение: 25.12.2017).

\section{Литература}

BEPHEP 2017

ВЕРНЕР И. В., “К истории перевода Псалтыри Максимом Греком в 1522-1552 годах: хронология, текстология, методология”, Славяноведение, 2, 2017, 40-54.

ИСАЧЕНКО 2002

ИсАченко Т. А., “Книга Иова в переводе монаха Чудова монастыря Моисея (1671 г.): особенности языка и историко-литературный контекст”, Древняя Русъ. Bопросы медиевистики, 2002, 4 (10), 67-75. 
The Book of Psalms in the Church Slavonic, Greek, and Polish Languages

from Simon Azarjin's Library

ДИАНОВА, КОСТЮХИНА 1980

ДиАновА Т. В., КостюХинА Л. М., Водяные знаки рукописей России XVII в. (По материалам Отдела рукописей ГИМ), Москва, 1980.

КАРСКИЙ 1896

КАРСКИЙ Е. Ф., Западнорусские переводы Псалтири в XV-XVII веках, Варшава, 1896. 1903

КАРский Е. Ф., Белорусы, 1: Введение в изучение языка и народной словесности, Варшава, 1903. 1908

КАРский Е. Ф., Белорусы, 2: Язык белорусского племени, Варшава, 1908.

КЕДРОВ 1892

КЕдРов Н. И., Просветительская деятельность Троице-Сергиевой лавры за первые три века ее существования, Москва, 1892.

\section{КлитинА 1979}

Клитина Е. Н., “Симон Азарьин (Новые данные по малоизученным источникам)”, in: Труды Отдела древнерусской литературы, 34, Ленинград, 1979, 298-312.

Клосс 1998

Клосс Б. М., Избранные труды, 1: Житие Сергия Радонежского, Москва, 1998. 2012

Клосс Б. М., О происхождении названия “Россия”, Москва, 2012.

КНИГА БЕЛОРУССИИ 1986

Книга Белоруссии. 1517-1917. Сводный каталог, Минск, 1986.

ЛЕонид 1883

ЛЕОНид (КАВЕЛИН), “Сведения о славянских рукописях, поступивших из книгохранилища Свято-Троицкия Сергиевы Лавры в библиотеку Троицкой Духовной семинарии в 1747 году”, Чтения в Императорском Обществе Истории и Древностей Российских при Московском Университете, 4, 1883, 1-112.

НИКОЛАЕВА 2000

НиколАева С. В., “Троице-Сергиев монастырь в XVI - начале XVII века: состав монашеской братии и вкладчиков” (дисс. [. . .] канд. ист. наук, Москва, 2000).

Носович 1870

Носович И., Словарь белорусского наречия, С.-Петербург, 1870.

ОПАРИНА 1998

ОПАРина Т. А., Иван Наседка и полемическое богословие киевской митрополии, Новосибирск, 1998.

ПЕНТКОВСКАЯ 2016А

ПЕнтковскАя Т. В., “Перевод аргументов к книге Иова 1671 г. на фоне московских библейских переводов с польского языка”, Вестник Московского университета. Серия 9: Филология, 2, 2016, 10-39.

2016Б

ПентковскАя Т. В., “Новый Завет в переводе книжного круга Епифания Славинецкого и польская переводческая традиция XVI в.: перевод аргументов к Апостолу”, Русский язык в научном освещении, 1 (31), 2016, 182-227.

\section{РИБ VII}

Русская историческая библиотека, издаваемая Археографическою комиссиею, 7:

Памятники полемической литературы в Западной Руси, С.-Петербург, 1882.

СлРЯ XI-XVII вв.

Словарь русского языка XI-XVII вв., 1-30-, Москва, 1975-2015-. 


\section{Сопиков 1813}

Сопиков В. С., Опыт российской библиографии, или Полный словарь сочинений и переводов, напечатанных на славенском и российском языках от начала заведения типографий до 1813 года, 1, С.-Петербург, 1813.

Ундольский 1871

Ундольский В. М., Хронологический указатель славяно-русских книг иерковной печати с 1491-го по 1864-ый, 1: Очерк славяно-русской библиографии, Москва, 1871.

УСПЕНСКИЙ 1997

УСпЕнский Б. А., "Русское книжное произношение XI-XII вв. и его связь с южнославянской традицией (Чтение еров)”, in: IDEM, Избранные труды, 3: Общее и славянское языкознание, Москва, 1997, 143-208. 2002

УспЕнский Б. А., История русского литературного языка (XI-XVII вв.), Москва, 2002.

ЦЕЛУНОВА 1998

ЦЕлуновА Е. А., “Культурная и языковая ситуация Великого княжества Литовского”, in: AION. Slavistica: annali dell'Istituto universitario orientale di Napoli, 5: 1997-1998, Napoli, 2000, 33-109.

2006

ЦЕлуновА Е. А., предисл., исслед., подгот. текста, Псалтырь 1683 года в переводе Аврамия Фирсова: Текст, словоуказатель, исследование, Москва, 2006.

BunČIĆ 2012

Bunčić D., "The Standardization of Polish Orthography in the 16th Century,” in: S. BADdeley,

A. Voeste, eds., Orthographies in Early Modern Europe, Berlin, 2012, 219-254.

FRICK 1989

FRICK D. A., Polish Sacred Philology in the Reformation and the Counter-Reformation. Chapters in the History of the Controversies (1551-1632) (= University of California Publications in Modern Philology, 123), Berkeley (CA), 1989.

GreK-Pabisowa, MaryniaKowa 1997

Grek-PABisowa I., MARYNiAKowA I., "Język polski na Kresach północno-wschodnich dawniej i dziś," in: I. Grek-PABisowa, ed., Historia i wspótczesność języka polskiego na Kresach wschodnich, Warszawa, 1997, 27-109.

KURYŁOWICZ 2005

KURYŁOWICZ B. I., Język polski w szesnastowiecznych księgach miejskich Knyszyna, Białystok, 2005.

KuRzowA 1993

KuRzowa Z., Język polski Wileńszczyzny i Kresów pótnocno-wschodnich XVI-XX w., Warszawa, Kraków, 1993.

2006

Kurzowa Z., Polszczyzna Lwowa i Kresów południowo-wschodnich do roku 1939, Kraków, 2006.

LINDE 1807-1808, 1.I-II

LINDE S. B., Stownik języka polskiego, 1.I-II, Warszawa, 1807-1808 (http://www.kpbc.umk.pl/ publication/8173; последнее обращение: 25.12.2017).

LUTO-KAMIŃSKA 2015

Luto-KAMIŃSKa A., "Alfurkan tatarski Piotra Czyżewskiego - opis zabytku (grafia z elementami fonetyki)," in: Studia z Filologii Polskiej i Stowiańskiej, 50, 2015, Warszawa, 18-47.

MARTEL 1938

MARTEL A., La langue polonaise dans les pays ruthenes. Ukraine et Russie Blanche. 1569-1667,

Lille, 1938. 
The Book of Psalms in the Church Slavonic, Greek, and Polish Languages

from Simon Azarjin's Library

\section{MOSER 2002}

Moser M., "Zur Polszczyzna kresowa in Weißrussland und der Ukraine und ihrer sprachlichen Charakteristik," Die Welt der Slaven, 47, 2002, 31-56.

PiETKIEWICZ 2002

PietKIEWICZ R., Pismo Święte w języku polskim w latach 1518-1638. Sytuacja wyznaniowa w Polsce a rozwój edytorstwa biblijnego, Wrocław, 2002.

\section{SEMKowicz 1951}

Semkowicz W., Paleografia Łacińska, Kraków, 1951.

\section{SICIŃSKA 2015}

SiciŃSKA K., "Cechy fonetyczne polszczyzny południowokresowej w listach metropolity kijowskiego Jana (Hioba) Boreckiego z lat 1624-1629," Rozprawy Komisji Językowej ŁTN, 61, $2015,199-220$.

\section{S£P XVI}

Stownik polszczyzny XVI wieku, 1-36, Wrocław, Warszawa, Kraków, Gdańsk, 1966-2012 (http://spxvi.edu.pl/; последнее обращение: 25.12.2017).

\section{SŁP XVII}

Elektroniczny stownik języka polskiego XVII i XVIII wieku (http://sxvii.pl/; последнее обращение: 25.12.2017).

\section{References}

Bunčić D., "The Standardization of Polish Orthography in the 16th Century," in: S. Baddeley, A. Voeste, eds., Orthographies in Early Modern Europe, Berlin, 2012, 219-254.

Celunova Je. A., "Kul'turnaia i iazykovaia situatsiia Velikogo kniazhestva Litovskogo," in: AION. Slavistica: annali dell'Istituto universitario orientale di Napoli, 5: 1997-1998, Napoli, 2000, 33-109.

Celunova Je. A., Psaltyr' 1683 goda v perevode Avramiia Firsova: Tekst, slovoukazatel', issledovanie, Moscow, 2006.

Dianova T. V., Kostiukhina L. M., Vodianye znaki rukopisei Rossii XVII v., Moscow, 1980.

Frick D. A., Polish Sacred Philology in the Reformation and the Counter-Reformation. Chapters in the History of the Controversies (1551-1632) (= University of California Publications in Modern Philology, 123), Berkeley (CA), 1989.

Grek-Pabisowa I., Maryniakowa I., "Język polski na Kresach północno-wschodnich dawniej i dziś," in: I. Grek-Pabisowa, ed., Historia i wspótczesność języka polskiego na Kresach wschodnich, Warszawa, 1997, 27-109.

Isachenko T. A., "Kniga Iova v perevode monakha Chudova monastyria Moiseia (1671 g.): osobennosti iazyka i istoriko-literaturnyi kontekst," Drevnyaya Rus. Voprosy Medievistiki, 2002, 4 (10), 67-75.

Klitina E. N., "Simon Azar'in (Novye dannye po maloizuchennym istochnikam)," in: Trudy Otdela drevnerusskoi literatury, 34, Leningrad, 1979, 298-312.

Kloss B. M., Izbrannye trudy, 1: Zhitie Sergiia Radonezhskogo, Moscow, 1998.
Kloss B. M., O proiskhozhdenii nazvaniia "Rossiia”, Moscow, 2012.

Kuryłowicz B. I., Język polski w szesnastowiecznych księgach miejskich Knyszyna, Białystok, 2005.

Kurzowa Z., Jezzyk polski Wileńszczyzny i Kresów pótnocno-wschodnich XVI-XX w., Warszawa, Kraków, 1993.

Kurzowa Z., Polszczyzna Lwowa i Kresów południowo-wschodnich do roku 1939, Kraków, 2006.

Luto-Kamińska A., "Alfurkan tatarski Piotra Czyżewskiego - opis zabytku (grafia z elementami fonetyki)," in: Studia z Filologii Polskiej i Stowiańskiej, 50, 2015, Warszawa, 18-47.

Martel A., La langue polonaise dans les pays ruthènes. Ukraine et Russie Blanche. 1569-1667, Lille, 1938.

Moser M., "Zur Polszczyzna kresowa in Weißrussland und der Ukraine und ihrer sprachlichen Charakteristik," Die Welt der Slaven, 47, 2002, 31-56.

Oparina T. A., Ivan Nasedka i polemicheskoe bogoslovie kievskoi mitropolii, Novosibirsk, 1998.

Pentkovskaya T. V., "The Translation of the Arguments to the Book of Job, 1671, against the Background of Moscow Biblical Translations from Polish," Moscow State University Bulletin. Series 9. Philology, 2, 2016, 10-39.

Pentkovskaya T. V., "The New Testament in the Translation of the Circle of Epiphanius Slavinetsky and the Polish Translation Tradition of the 16th Century: Translation of Summae in the Apostolos," Russian Language and Linguistic Theory (Russkij yazyk $v$ nauchnom osveshchenii), 1 (31), 2016, 182-226. 
Pietkiewicz R., Pismo Święte $w$ języku polskim $w$ latach 1518-1638. Sytuacja wyznaniowa w Polsce a rozwój edytorstwa biblijnego, Wrocław, 2002.

Semkowicz W., Paleografia Łacińska, Kraków, 1951.

Sicińska K., "Cechy fonetyczne polszczyzny południowokresowej w listach metropolity kijowskiego Jana (Hioba) Boreckiego z lat 1624-1629," Rozprawy Komisji Językowej ŁTN, 61, 2015, 199-220.
Uspenskij B. A., Izbrannye trudy, 3: Obshchee $i$ slavianskoe iazykoznanie, Moscow, 1997.

Uspenskij B. A., Istoriia russkogo literaturnogo iazyka (XI-XVII vv.), Moscow, 2002.

Verner I. V., "On the History of Maximus the Greek's Translation of Psalter in 1522-1552: Chronology, Textology, and Methodology," Slavianovedenie, 2, 2017, 40-54.

\section{Jelena Celunova, CSc.}

docentka katedry jazyků

Vysoká škola hotelová v Praze 8, spol. s r.o.

Svídnická 506

18100 Praha 8

Česká republika / Czech Republic

celunova@vsh.cz 